Allan H. Meltzer is a professor of political economy and publlc policy at Carnegie Mellon University and is a visiting scholar at the American Enterprise Institute. This paper, the fith annual Homer Jones Memorial Lecture, was delivered at Washington University in St. Louis on April 8, 1991. Jeffrey Liang provided assistance in preparing this paper. The views expressed in this paper are those of Mr. Meltzer and do not necessarily reflect official positions of the Federal Reserve System or the Federal Reserve Bank of St. Louis.

\title{
U.S. Policy in the Bretton Woods Era
}

T IS A SPECIAL PLEASURE for me to give the Homer Jones lecture before this distinguished audience, many of them Homer's friends.

I first met Homer in 1964 when he invited me to give a seminar at the Bank. At the time, I was a visiting professor at the University of Chicago, on leave from Carnegie-Mellon. Karl Brunner and I had just completed a study of the Federal Reserve's monetary policy operations for Con. gressman Patman's House Banking Committee. Given its auspices, the study caught the attention of many within the Federal Reserve. It was not surprising, then, that Homer invited me to visit. The report had raised issues in which Homer had a long-standing interest. One of these was the issue of monetary control procedures.

Although Homer was sympathetic to our criticisms, he was not easily persuaded about our proposals-such as monetary base control. Later, knowing him much better, I would say he was not easily persuaded about very much. You had to convince Homer with facts. He respected facts much more than clever arguments.

Homer's concern for facts never left him. It is not an accident that under his leadership, the economic staff at St. Louis began publishing those data triangles that economists all over the world now rely on when they want to know what has happened to monetary growth and the growth of other non-monetary aggregates. I am persuaded that the publication and wide dissemination of these facts in the 1960 s and 1970 s did much more to get the monetarist case accepted than we usually recognize. 1 don't think Homer was surprised at that outcome. He believed in the power of ideas, but he believed that ideas were made powerful by their cor. respondence to facts.

When Karl Brunner and I started the Shadow Open Market Committee, we invited Homer to be a member. He was a valuable and conscientious member who came to the meetings for many years armed with the kind of penetrating questions that one learned to expect from him. When he believed that his energy had declined and he could not contribute as fully and force. fully as in the past, he offered to resign. We persuaded him to stay on. He remained through the first ten years, leaving after the September 1983 meeting, only a few years before his death in 1986 .

One of the facts about monetary policy during Homer's years at the St. Louis Federal Reserve Bank is that the United States was part of the 
Bretton Woods system, in fact at the center of the system. Bretton Woods and international monetary policy were not major concerns of the Federal Reserve however, despite the formal commitment to the system and the responsibility implied by the role of the dollar. The failure to honor the commitment is one part of the in* flationary policies of that period. I am pleased to review and interpret the main facts about that experience in this lecture in honor of Homer Jones.

In the 45 years following World War II, there was a remarkable transformation of the international monetary system. At the war's end, the dollar was the dominant currency for international transactions and was universally held as a reserve asset or store of value. The Bretton Woods system recognized this role by making the dollar the principal reserve currency of the international system with the British pound as a second reserve currency. Exchange rates of other currencies were fixed to the dollar but were adjustable under conditions defined by the agreement. But, by 1971 the Bretton Woods system was in shambles, and in 1973 major countries agreed to experiment with fluctuating exchange rates.

This paper is about the history of U.S. international economic policy under Bretton Woods from 1959 to 1973 . The period begins with the recognition of a problem that was to become the central problem of the international monetary system for the next decade. At first, the problem was seen as a temporary balance of payments problem-the inability of the United States to balance its trade and payments at the prevailing fixed exchange rates. The end of this historical era is fixed by the decision in March 1973 to abandon fixed exchange rates between principal currencies. The starting point, 1959 , is the year major currencies became convertible, subject in many cases to restrictions on capital movements that were increased or relaxed as reserve positions changed.

Soon after the start of the period, and at the end, policymakers expressed concern about the competitive position of the U.S. economy. This concern about competitiveness returns again and again in the next four decades, although the focus of concern and the principal manifestation of the alleged problem shift. The alleged cause in 1959-60 was trade discrimination, which had been accepted by the United States at the end of the war to assist in the recovery from wartime destruction abroad. Soon after, the costs of foreign assistance and foreign military expenditures were added as causes. By the late 1960s these concerns and concern about foreign investment led successive administrations to restrict payments to foreigners by means such as the interest equalization tax, taxes on tourist expenditures, "buy America" programs, and "temporary" controls of foreign investment. Inflationary financing of the war in Vietnam and of domestic social spending more than offset any effect these programs may have had on the equilibrium value of the fixed, nominal exchange rate. Increasingly, the problem came to be seen as an exchange rate problem, specifically an overvalued dollar. As the Bretton Woods system ended, the dollar was first devalued against gold and major currencies, then allowed to fluctuate.

In the U.S. system, principal responsibility for international economic policy rests with the Treasury. The Federal Reserve is formally of secondary importance. Under Bretton Woods the Federal Reserve's main responsibility was to conduct monetary policy so as to maintain the fixed exchange rate agreed to by the administration. There is no specific legistative authorization for the Federal Reserve to buy and sell foreign currencies (Schwartz 1991). But the Federal Reserve had a larger, informal role. Officials and staff participated in international meetings, gave advice and counsel on what were seen to be the principal problems of the Bretton Wood system, and proposed solutions. They participated, as observers, at the regular meetings of the Bank for International Settlements, where central bankers held regular discussions and reviews of U.S. policies. There is little evidence, however, of any systematic effort by the Federal Reserve to conduct monetary policy in a manner consistent with the requirements of a fixed exchange rate system. And, there is no evidence that any of the administrations objected to this neglect. On the contrary, from the Kennedy to the Nixon administrations, domestic economic policy objectives, though frequently changed, were of over. riding interest.

\section{TH UNTTED STATES TN TET BRETTON WOODS SVGTRN}

The Bretton Woods agreement of 1944 established a system of fixed exchange rates based on gold valued at $\$ 35$ per ounce. The 
agreement was the product of extensive negotiations, with much of the work done by the United States and British Treasuries. The intention of the drafters, principally John Maynard Keynes in Britain and Harry Dexter White in the United States, was to establish a set of rules to replace the rules of the international gold standard and to avoid the rigidity of that system. Because the British feared that the United States would return to the protectionist and deflationary policies of the interwar years, there were safeguards against that occurrence. U.S. infla* tion was considered unlikely or, more accurately, was not considered at all, so there were no rules for adjustment to prevent inflation from spreading to countries in the fixed exchange rate system.

The agreement obligated countries to intervene to keep their currencies within 1 percent of their fixed but adjustable (dollarl parities. As the principal reserve currency, the United States was obligated to buy and sell gold for dollars (or convertible currency) at the $\$ 35$ price. When the system started, the United States held about $3 / 4$ of the world's monetary gold stock. Currencies other than the dollar were inconvertible. By 1960, the U.S. gold stock had fallen, but the U.S. still held $\$ 20$ billion, almost half of all monetary gold. In the early years, the United States's loss of gold was looked on favorably as a step toward convertibility. By the end of 1958 , major currencies had become convertible for current transactions. ${ }^{3}$

The strengthening of foreign economies was a major aim of early postwar U.S. economic policy. At first, balance of payments deficits, foreign accumulation of dollars, and the redistribution of the gold stock were seen as desirable steps toward a viable international monetary system. By 1960, official concern about continued U.S. payments deficits began to be expressed. ${ }^{2}$ "The President's Economic Report for 1960, the last report prepared by the Eisenhower administration, discusses the competitive problems of the steel and automobile industries in world markets during 1959 and the growth of U.S. investment abroad, problems that were to remain for years to come (ERP, 1960). ${ }^{3}$ Suggested remedies are limited to pro-competitive policies, such as the removal of quantitative restrictions against imports from the United States, and to recommendations that foreign governments increase lending to developing countries.

The major problem at the time was not a U.S. current account deficit. Throughout the 1960s, the United States typically had a surplus on current account. The problem was that the trade and current account surpluses were not large enough to finance net private investment abroad plus military, travel, and foreign aid spending abroad. To settle the balance, the United States either had to sell gold or accumulate dollar liabilities to foreigners. As the gold reserve declined and liabilities rose, concern increased that the liabilities would become too large relative to the gold reserve to maintain confidence that the gold price would remain fixed. Under Bretton Woods rules, foreigners had the option of converting dollars into gold; the United States had responsibility for keeping the gold price fixed by permitting conversions and, at a more basic level, adjusting the production of dollars to maintain confidence in future gold convertibility. This part of the agreement was an early casualty. As foreign liabilities rose, restrictions were placed on gold sales to private holders and pressure or persuasion was used to discourage central banks and governments from converting dollars into gold.

Deficits and foreign dollar accumulation was not the only problem in the system as seen by U.S. policymakers at the time. A steady surplus in the U.S. balance of payments would have transferred gold and dollars to the United States. Since dollar balances were part of foreign reserves, but not U.S. reserves, total world reserves would fall. A U.S. surplus was seen as undesirable, therefore. Under a U.S. payments deficit, conversion of dollars into gold left world reserves unchanged but lowered the gold reserves behind the principal reserve currency. With growing foreign trade, and an implicit assumption that imbalances increase with trade, reserves would prove inadequate to finance imbalances at fixed exchange rates and a fixed gold price.

Germany permited convertibility on capital account at the same time. The Japanese yen did not become convertible on current account until 1964.

औ will refer to these reports as ERP (year).

2For the year 1959 as a whole, the U.S balance on current account was negative, $-\$ 1.3$ billion, for the first time since 1953. 


\section{Figure 1 \\ U.S. Gold Reserves and Liabilities to Foreign Central Banks and Governments}

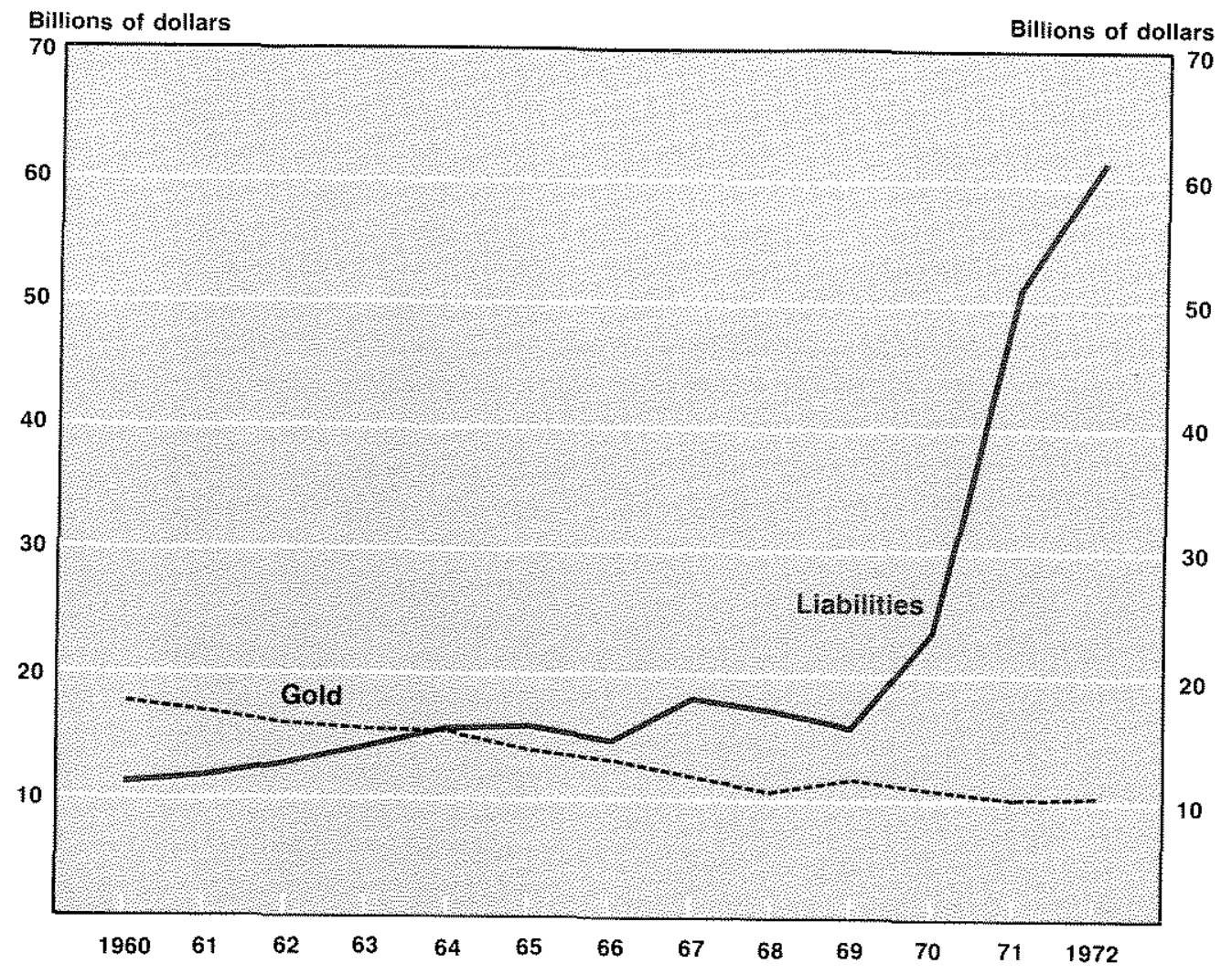

Figure 1 shows U.S. gold reserves and dollar liabilities to foreign central banks and governments for the period as a whole. The dollar liabilities shown in the figure were generally about half the size of total U.S. liabilities to foreigners. Dollar liabilities mounted, at first gradually, then more rapidly. By 1964, liabilities to central banks were equal to the U.S. gold reserve and by 1970 were twice the level of the reserve.

It seems clear in retrospect, as it did to some at the time, that the Bretton Woods system had a serious flaw. If foreign trade and payments imbalances rose with the growth of world income, there would be growth in the demand for world reserves. For a time, the demand could be met, as it had been, by increased foreign holdings of dollars and a decline in U.S. gold reserves. By the time recovery from wartime destruction abroad reached the point that re- strictions on convertibility could be removed. the United States was losing gold and accumulating liabilities at rates that threatened the system's long-term stability.

Under the Marshall Plan (1948-52) U.S. policy encouraged foreign governments to rebuild reserves as a step toward convertibility. Countries were permitted, and even encouraged, to export to the U.S. while restricting imports from the United States. When the Marshall Plan ended, military expenditures to support military commitments and aid to developing countries maintained a flow of dollars equal to more than $\$ 2$ billion a year. This helped western European countries as a group to achieve a current account surplus by the mid-1950s, despite a continuing trade deficit. Convertibility for current account transactions at the end of 1958 (as well as for capital account transactions in Germany) 
plus the commitment to reduce internal trade barriers as part of a common market stimulated U.S. investment in Europe. Hence, a capital inflow augmented the stock of foreign exchange reserves in countries outside the United States. In the two years 1958 and 1959, gold and dollar reserves of the principal European countries increased by $\$ 5$ billion, about 25 percent of total U.S. reserve assets at the end of the period. ${ }^{5}$

There were four possible solutions (Friedman, 1953): (1) devaluation against gold and major currencies, (2) deflation, (3) borrow as long as foreigners would lend, and (4) impose controls of various kinds. Several of these solutions could be achieved in different ways. For example, foreigners could revalue against the dollar. Or, foreigners could inflate faster than the United States, thereby changing the relative prices of domestic and foreign goods at fixed exchange rates.

\section{Policies of the Kennedy and Johnson Administrations}

Under Bretton Woods rules countries were permitted to devalue up to 10 percent without consultation when faced with "fundamental disequilibrium." The precise conditions characterizing fundamental disequilibrium were not spelled out, and the International Monetary Fund (IMF) did nothing to clarify the conditions. The drafters had wanted to avoid both the inflexibility of the classical gold standard and the competitive devaluations of the interwar period. The language may have been intended to permit devaluation if the alternative was deflation while avoiding devaluation if a country could expect to restore payments' balance and repay a shortor medium-term adjustment loan.

Devaluations by major countries occurred. In the early years several countries followed the United Kingdom in a 30\% devaluation in 1949. France devalued by 29 percent in 1958 , and the United Kingdom devalued again in 1967. The United States chose to regard its problem as less than "fundamental." President Kennedy came in-

\footnotetext{
4See ERP (1959).
}

sTotal U.S. reserve assets include the total U.S. gold stock and its reserve position in the International Monetary Fund. At the end of 1959 , these balances were $\$ 19.5$ and $\$ 2.0$ billion respectively. ERP (1971).

The Kennedy Treasury led by Douglas Dillon and Robert Roosa was firmly opposed to devaluation. Dillon was an investment banker, and a Republican, who had served as to office committed to maintain the $\$ 35$ gold price but also to "get the economy moving" after the relatively slow growth and two recessions in the previous four years. The commitment to a fixed nominal gold price ruled out devaluation of the dollar against gold and all other currencies; the commitment to higher economic growth removed the classical remedy, deflation of domestic prices and costs of production to raise the real dollar value of the U.S. gold stock and lower the relative price of U.S. exports. That left borrowing, controls and foreign inflation as the principal options.

The decision to avoid devaluation and deflation reflects some strongly held views of the period. The $\$ 35$ gold price was seen as a firm commitment under the Bretton Woods Agreement. If the United States devalued once, it could do so again, with costs to the stability that Bretton Woods was supposed to provide. Avoiding repetition of the experience with deflation in the early 1930s and the decade-long depression was a major factor in the passage of the Employment Act and the Bretton Woods agreement. Few wished to repeat the prewar experience even in milder form. Hence, the Kennedy administration met little opposition from business or political groups in excluding the price options, devaluation and deflation. ${ }^{6}$

Kennedy's main domestic campaign theme had been getting the economy "moving" after the relatively slow average growth rate of the second Eisenhower administration. The Kennedy administration policies emphasized domestic growth, full employment and price stability as their major aims and relied on a so-called fiscal monetary mix to stimulate output while reducing the capital outflow. In practice, this translated into a series of tax measures-faster depreciation for capital, an investment tax credit and, later, reductions in personal and corporate tax rates. To limit the capital outflow, the administration tried to prevent a sharp counter cyclical decline in interest rates during the early months of the recovery from the $1960-61$ reces- ambassador to France. Roosa had been a senior economist at the N.Y. Fed and was very attracted to activist policies whether in domestic credit markets or international markets. At the Council of Economic Advisers (CEA), Walter Heller was mainly interested in domestic policy. Heller (1966) says very little about the dollar problem other than noting that the balance of payments required higher short-term interest rates. Kennedy saw the problem as a matter of prestige. Sorensen (1965), pp. 405-12. 


\section{Figure $2 a$ \\ Federal Funds Rate During the 1960s}

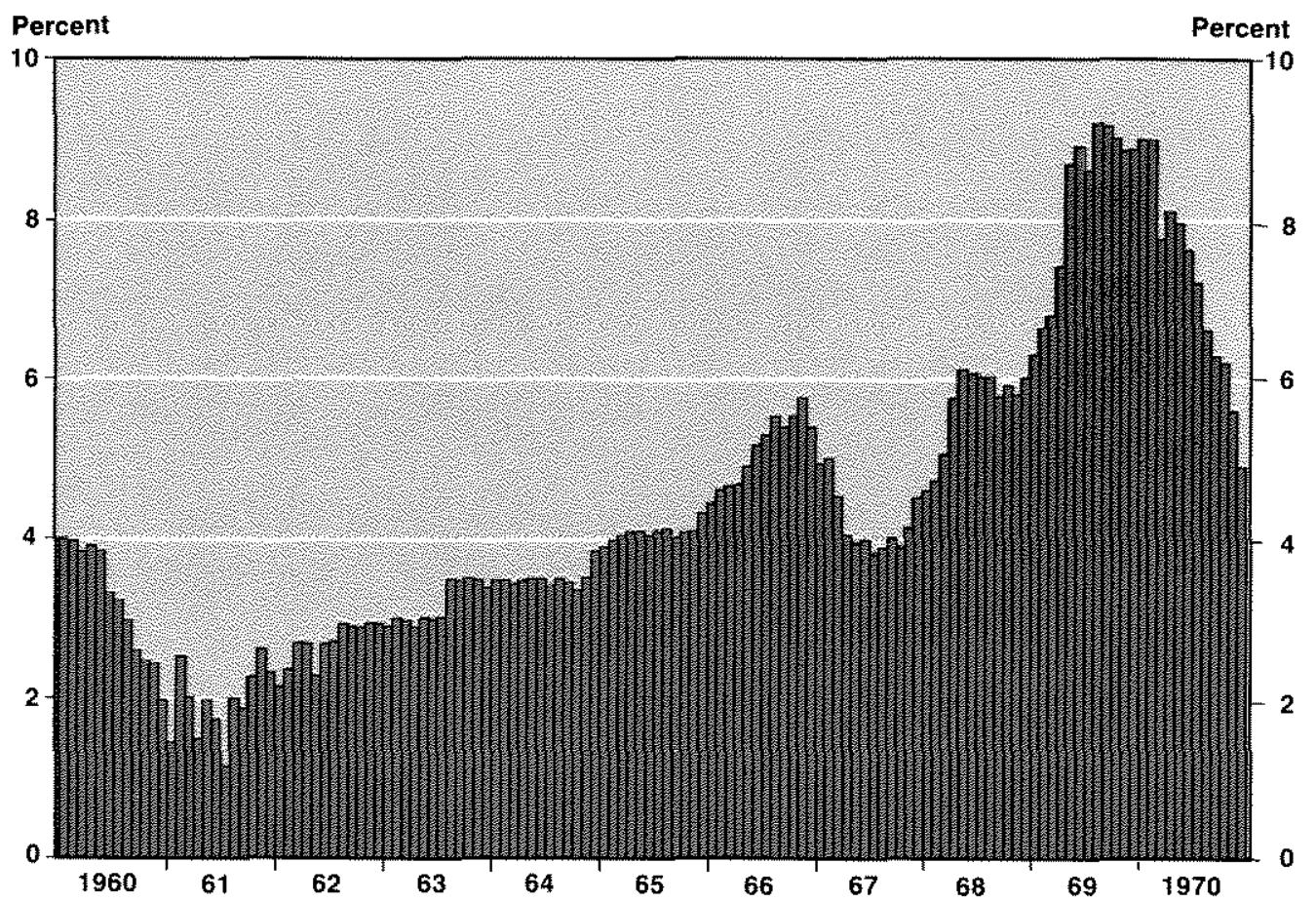

sion. ${ }^{7}$ In cooperation with the Federal Reserve, the Treasury attempted to "twist" the yield curve by buying long-term bonds and selling shortterm Treasury bills. ${ }^{8}$ Since the market for government securities is very active and highly competitive, participants were able to reverse any temporary change in interest rates achieved by the twist.

Neither money growth nor interest rates shows evidence of "tight money" in the early 1960s. Figure 2a shows the federal funds rate for that decade. The funds rate is the rate most tightly controlled by the Federal Reserve. From 1961 to 1966 , the rate rose slowly, and it did not exceed 3 percent until late in 1963. Figure $2 \mathrm{~b}$ shows the growth rate of the monetary base for the same period. The growth rate is com. puted as the percentage rate of change from the corresponding month of the preceding year. Shortly after the Kennedy administration came into office, growth of the base rose to about $1-1 / 2$ to 2 percent. By mid-1963 the growth rate of the base was consistently above the longterm growth of output, 3 percent per annum. Growth of the base continued to rise in 1964 .

With the possible exception of 1961-62, base growth shows no evidence that monetary policy was relatively restrictive. In fact, base growth, far from being deflationary, was inconsistent with continuation of the relatively low rate of inflation inherited from the past. To prevent higher inflation, the Kennedy administration introduced informal guidelines for prices and wages. The prevaling view was set out in the
${ }^{7}$ See Heller (1966), p. 5.

8The Treasury also auctioned "strips" of bils that required dealers to buy more than one issue at a time on the im- plausible assumption that the additional distribution cost would be treated by the market as a rise in the effective interest rate instead of a fee for service. 


\section{Figure 2b \\ Annual Growth of the Monetary Base During the 1960 s}

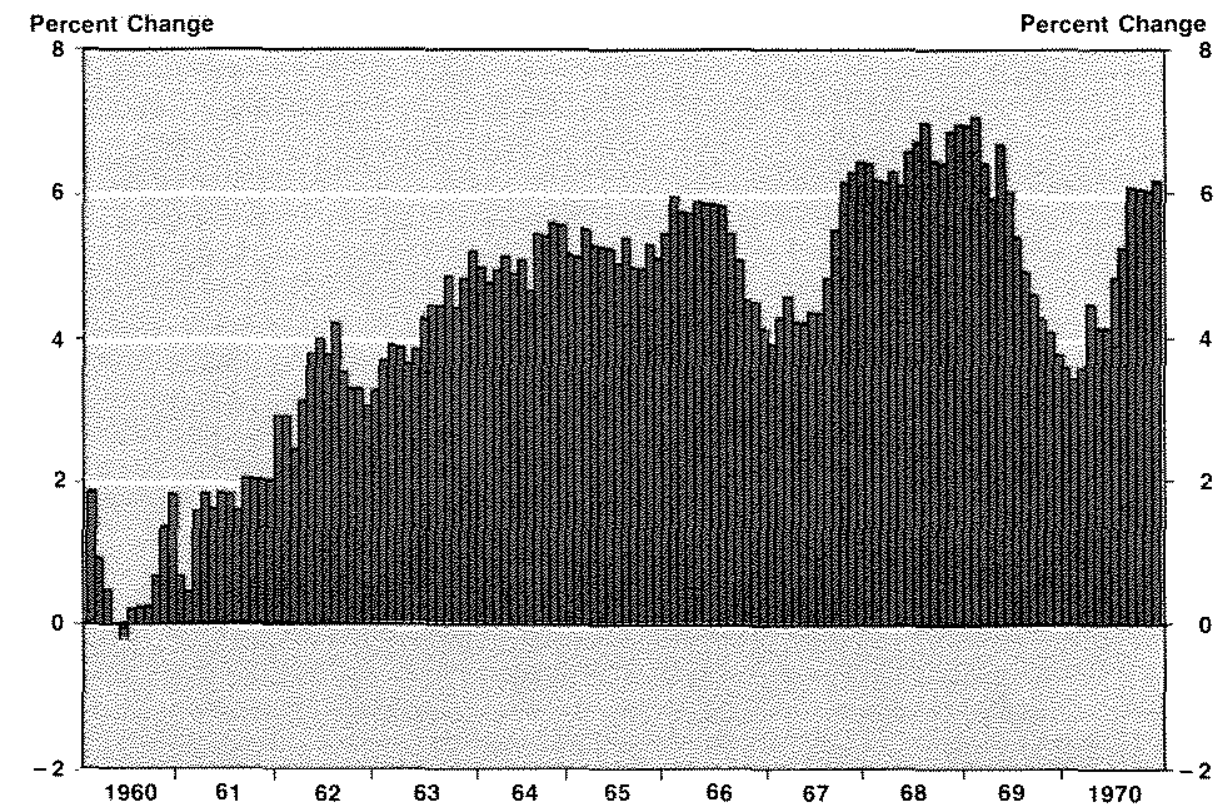

1962 Economic Report of the President. In this view, a relatively stable Phillips curve permitted policymakers to trade higher inflation for lower unemployment. The price and wage guidelines were supposed to improve the trade-off by reducing wage and price increases as the economy approached full employment.

A slow recovery gave way in 1963 to robust real growth. Inflation remained low. Until 1965, the fixed weight deflator rose between 1 percent and 1-1/2 percent annually and the consumer price index between $3 / 4$ percent and 2 percent. Inflation was generally higher abroad, so relative prices of U.S. goods declined. Figure 3 shows the ratio of the U.S. consumer price index to a trade-weighted average of consumer prices abroad, based on the weights in Federal Reserve index of nominal exchange rates. The index shows the sustained relative decline in the U.S. price level during the first half of the decade. With few exceptions, the ratio declined

3Various definitions were used but the official settlements balance appears to have been the main concern. This balance consists of current account plus long-term capital flows plus net private shori-tern capital flows. I report this balance from time to time in the text, but 1 base my judgments much more on the current account balance. The monthly until 1966. CPIs are relatively comprehensive measures but, as is well known, not perfect measures of traded goods and services. Doubtless there are temporal differences between the price ratio in figure 3 and ratios computed using other prices, but the pattern of persistent decline would be little affected.

Under the impact of relative price changes and other factors, the merchandise trade balance increased. U.S. capital investment abroad continued to rise and domestic and foreign borrowers used the U.S. market to raise funds for investment abroad, so the capital outflow continued.

\section{Special Measures}

From 1960 on, each administration sustained or strengthened controls on trade and payments intended to reduce the balance of payments deficit. ${ }^{9}$ At first, the measures consisted of

concern about profitable investment abroad puzzles me; investment of this kind produces a subsequent intlow. Also, the current account balance is more usefut for comparison of the fixed and fluctuating rate periods. On the role of the current account see Corden (1990). 


\section{Figure 3 \\ Index of the Ratio of U.S. CPI to Trade-Weighted CPI}

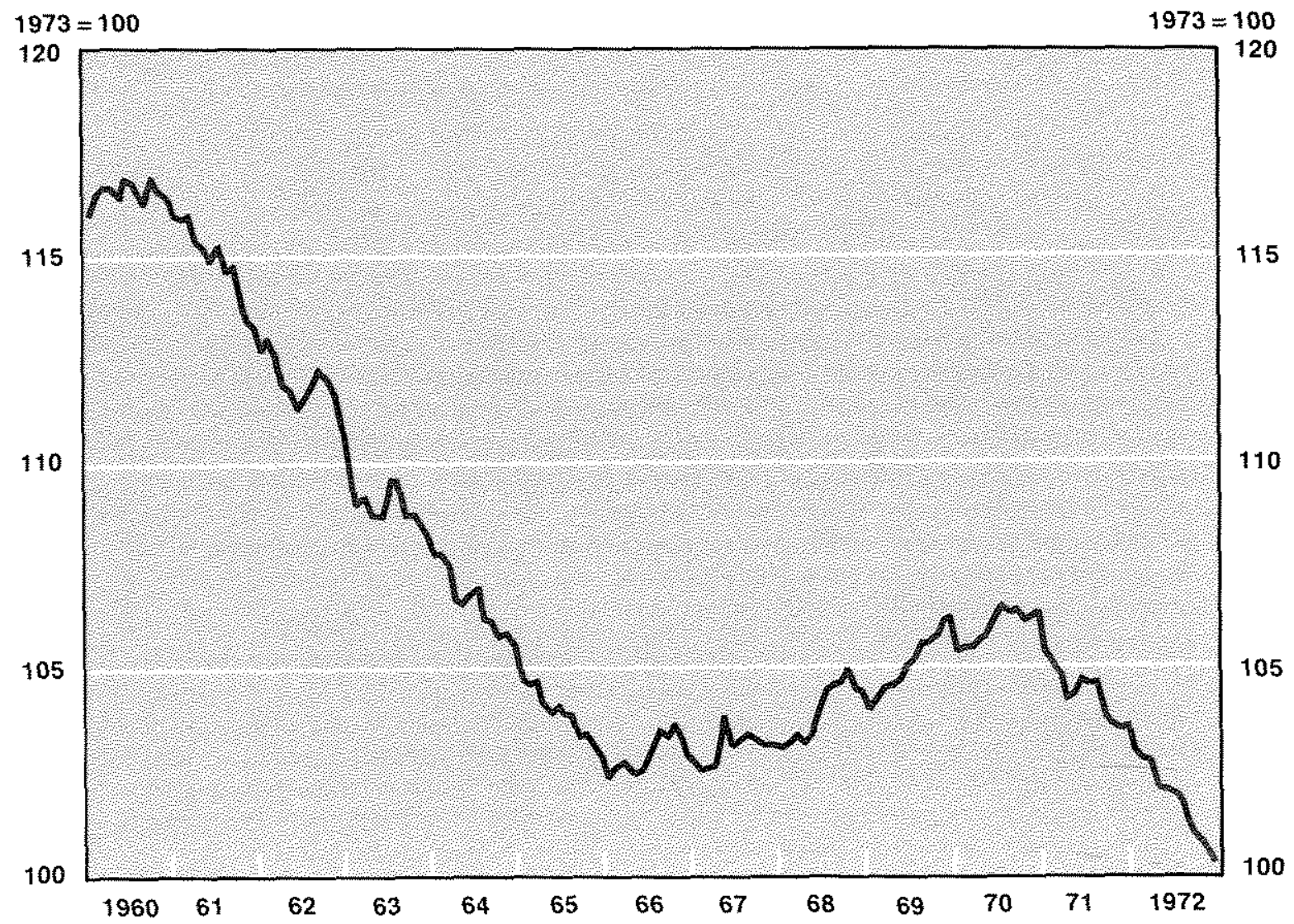

relatively modest steps to encourage exports (by subsidized loans from the Export-Import Bank) or to purchase military equipment and supplies in the United States even if it imposed higher costs. Within a few years, the list of controls and their efficiency cost increased. Development aid was tied to dollar purchases. An "interest equalization" tax was put on foreign borrowing and later raised. Most tourist expenditures were made dutiable. And guidelines were used to further limit the expansion of bank lending to for. eigners and to limit growth of foreign direct investment. Table 1 lists some of the measures proposed or adopted.

The efficacy of the controls varied with the opportunity or ability to substitute uncontrolled for controlled transactions. Tieing military expen- ditures is inefficient to the extent that it raises costs, but substitution is probably limited. Re. quiring foreigners to pay the cost of U.S. troops abroad increases exports and the current account and reduces the capital outflow. Tieing foreign aid or military spending reduces the real value of the spending but may lead to higher appropriations, so that over time the actual dollar outflow is not much affected. Restrictions on foreign borrowing in the U.S. market are circumvented if foreigners or domestic citizens sell their holdings of dollar securities to pur. chase new issues sold abroad. Further, restrictions of foreign lending and investment affect relative rates of interest at home and abroad thereby reducing the effect of the restrictions. And foreign firms import fewer goods from the United States. 


\section{Table 1}

\section{Selected Balance of Payments Measures (Actual and Proposed)}

1960 . Expatision of Export Inport Bank lending and guarantees of non-commercial risks: Reduction in miltary dependents abroad (repealed in 1961 )

Reduction in defense and non defense government purchases abroad.

1961 Oflsets for military expenditure it Elope and additional procurement at home.

Tieing development aid to Gollar purchases.

increased laxes on foreign eamings of US. corporations:

Reduced allowance for tourist purchases abroad from $\$ 500$ 10 $\$ 100$

Treasub intervention in foregn exchange narkets.

Repavment of German loans.

1962 Expansion of earlier programs

Offset purchases by Gemany and llaly:

hereased borrowing authority tor the MF.

Beginning of Federal Reserve' 'swap' arangements tor cutrehcles

Treasury issues foregn denominated securities.

1963 An niterest equalkzation tax of $1 \%$ on toreign borrowers in 1.5 market Add tionat tieing of toregen aid to domestic purchases.

1965

Ihterest Equalization Tax on bank loans with duration of one year or more nade to bor. rowe os in developed counties (excepl Canada)

Livits on growh or bahk lending to loreigners.

Encourage pruale companies to nerease exports and repatriate earings.

Guideines tor dired nuestment by nonthanctal corpolations to imit growth of torelgh dired investhent

1967 Pernil higher tax rates (up to 20\%) ior hter est equalization 1 ax Expansion of lending authorty of Export Impon Bank

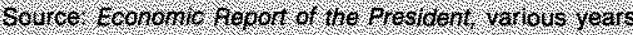

Controls and restrictions were, at best, a shortterm solution. Most of the controls and restrictions in table 1 were introduced as temporary measures, although several were extended and strengthened when renewed. Even if these measures had succeeded in stemming the balance of payments deficit, they did not offer a permanent solution at a new equilibrium without controls. The problem would have returned when the controls were removed.

To smooth fluctuations in the gold price and short-term capital movements, the Treasury introduced several measures. Eight countries joined a gold pool in 1961 to stabilize the London gold market. Reciprocal credit agreements (called "swaps") with foreign central banks and the Bank for International Settlements provided loans of foreign currencies and dollars. Typically the Federal Reserve borrowed to purchase dollars held abroad instead of selling gold. ${ }^{10}$ Swaps are a short-term accommodation. To repay the swaps, the Treasury began borrowing from foreign central banks at longer terms using bonds denominated in foreign currencies. The proceeds from the bond sales (called Roosa bonds) helped to repay the swaps without re. ducing the U.S. gold stock, again postponing the problem. Lending facilities of the IMF were expanded under the General Agreements to Borrow. The agreements provided that 10 countries would lend under specified conditions to augment the Fund's resources. This is the origin of the group of $10(\mathrm{G}-10) .{ }^{11}$ Again, these were mainly short-term measures.
10 See Solomon (1982), p. 42.

1 Canada, Japan, Belgium, France, Germany, ltaly, Netherlands, Sweden, United Kingdom, United States.
Later, Switzerland joined the G-10, but the name remained. 
The United States supplied 60 percent of the gold sold in the London gold market; the other members of $\mathrm{G}-10$ were supposed to provide the rest. Foreign countries replaced some of their sales by purchases from the United States, so the U.S. contribution to the pool, direct and indirect, became a major cause of the decline in the U.S. gold stock. In March 1968, with U.S. gold reserves under $\$ 11$ billion, the gold pool was abandoned. The price of gold for official transactions remained at $\$ 35$, but the $\mathrm{G}-10 \mathrm{gov}$ ernments did not attempt to control the price for private transactions. To prevent arbitrage, foreign central banks agreed not to sell in the gold market.

For the years $1960-67$ as a whole, the non-U.S. members of the G-10 (including Switzerland) acquired 150 million ounces of gold, an increase of one-third over their holdings at the end of $1960,{ }^{12}$ Every country except Britain and Canada added to its stocks. Britain sold 38 million ounces, the U.S. 164 million ounces. France acquired more than 100 million ounces, two-thirds of the total acquisition by $\mathrm{G} \cdot 10$ countries. ${ }^{13}$

The year 1966 is the peak year for gold holdings of the G-10, excluding the United States, and 1965 is the peak year for the eleven countries, measured in ounces of gold. In these years, the value of the stock at $\$ 35$ per ounce was approximately $\$ 15$ billion. The value of the U.S. stock was approximately $\$ 13$ billion, about equal to the non-gold foreign exchange holdings of the other members of the G-10. After 1968, nonU.S. members of the G-10 as a group reduced their stocks slightly until 1971 , but several acquired gold in the market. The embargo can be said to have succeeded in this limited sense.

Also in 1961, the 'Treasury's Exchange Stabilization Fund (ESF) began operations in foreign currencies for the first time since the 1930s. The Federal Reserve joined in these operations in 1962, and in 1963 the Fed began lending dollars to the Treasury secured by Treasury holdings of foreign exchange. These so-called "warehousing" operations permitted the Treasury to expand its purchases of foreign exchange without seeking Congressional appropri-

12All data on gold are from IMF (1990), p. 65

131967 is the peak for France's accumulation of gold. The following year France sold 40 million ounces to defend the franc's parity following the riots and disturbances.

14The analogy negiects the role of the pound as an alternative reserve currency, but its role was small and of declining importance. ations to support the activity. Warehousing remained small in the 1960 s but increased sub. stantially in the $1980 \mathrm{~s}$.

\section{Proposals for Long-Temm Adjustment}

The policies of the Kennedy and Johnson administrations may have stabilized the level of foreign official holdings in the years 1963-66 but, as shown in figure 1 above, U.S. gold reserves continued to decline. A popular analogy at the time treated the United States as a bank for the international monetary system. Foreign dollar holdings were considered the analogue of bank deposits and gold the analogue of bank reserves ${ }^{14}$ The analogy suggests that the series of mainly short-term, one-time or allegedly temporary measures, such as the interest equalization tax, had not solved the problem of a future run on the bank. The gold reserve continued to fall absolutely and relative to official (or total) dollar claims.

The Kennedy administration was aware of the long-term problem. In 1962, the administration asked economists at the Brookings Institution to study the longer-term prospects for balance of payments adjustment. The report took the "basic balance"-balance on goods and services, government payments plus long-term capital flow-as its standard. ${ }^{15}$ It projected that by 1968 this balance would be between a surplus of $\$ 1.9$ billion and a deficit of $\$ 600$ million, depending on the assumptions about growth, prices and costs at home and abroad. This section of the report was greeted warmly by the administration. The projected improvement reflected the assumption of a rise in foreign relative to domestic prices and a slowing of U.S. investment abroad as profit rates rose in the United States relative to abroad. The expected rise in domestic profit rates reflected the direet effect of the Administration's proposed reduction in corporate tax rates and the indirect, stimulative effect of tax rate reductions for households and businesses. ${ }^{16}$ As shown in figure 3 , a relative increase in prices abroad occurred, but the projections proved optimistic. The recorded 1967 balance was $-\$ 2.1$ billion. ${ }^{17}$

fo For the tax reduction to improve the basic balance, the rise in expected real returns in the U.S. had to overcome the expected positive effect of tax reduction on imports.

17 See EAP (1964), p. 131. 
The Brookings report also considered the effects of a U.S. Surplus in its basic balance on the supply of world reserves and concluded that either a new source of world reserves would have to be found, or there would have to be greater flexibility of exchange rates. The report discussed a dollar-pound bloc and a continental European bloc with fixed rates inside the bloc and fluctuating rates between the blocs. ${ }^{18}$ The Council of Economic Advisers summary of the Brookings study has no reference to this discussion.

The Council of Economic Advisers argued that, although the Bretton Woods agreement permitted exchange rate adjustments, "for a reserve currency country, this alternative is not available."19 And, they added, "for other major industrial countries, even occasional recourse to such adjustments would induce serious speculative capital movements, thereby accentuating imbalances." "2o

With exchange rates adjustments ruled out, only two alternatives were considered. One was increased fiscal expansion by surplus countries and less expansive policies for countries in deficit. The other was introduction of some type of new reserve asset. The latter proposal led eventually to the creation of special drawing rights (SDRs).

This was the heyday of Keynesian policy, so it is not surprising that Keynesian policies have a prominent place in administration proposals. The administration favored a policy mix and what later became known as policy coordination. Under the fixed exchange rate system, countries were expected to buy and sell dollars to maintain their exchange rate. The economic reports of the President for the period assumed, however, that countries can adjust capital flow by varying the mix of fiscal and monetary policies. The ERP argues that "flexible changes in the mix of fiscal and monetary policies can serve to reconcile internal and external policy goals." For the United States, the prescription was tax reduction to expand domestic spending while holding short-term interest rates high to reduce short-term capital outflow. Surplus countries with strong domestic demand were called upon to raise tax rates or lower government spending and expand money growth to lower interest rates. The idea was that the inflationary consequences of domestic monetary expansion would be reduced or avoided by the restrictive fiscal policy.

The International Monetary Fund's annual report for the period offers similar advice, but it warns of an inflationary bias. Surplus countries are subject to upward adjustment of wages and prices, but deficit countries are not subject to downward adjustments. ${ }^{22}$ The IMF recognized that world trade had grown faster than the gold stock, but they limited their recommendation to a study of possible future needs. ${ }^{23}$

The Germans, to whom the recommendation for monetary expansion and fiscal restraint was often directed, were skeptical about the policy mix proposals. Their expressed concern was the inflationary consequences of U,S. money growth. They held to a more classical view that the probblem was expansionary U.S. monetary policy, so it must be solved by restrictive policies in the United States, not expansive German policies. Their skepticism about "coordination" became a persistent feature of the policy dialogue under both fixed and fluctuating exchange rates.

Initially the German response was to discourage capital inflows. For example, German banks were required to hold relatively high reserve requirements against foreigners' deposits. The Germans argued, against the spirit of the Bretton Woods agreement, that deficit countries should adjust. They opposed revaluation of the mark even more strongly than they opposed domestic expansion, since they could avoid revaluation but could avoid expansive monetary policy only by imposing severe restrictions on capital inflows.

After much delay, and many denials, Germany revalued the mark by 9.3 percent in October $1969 .{ }^{24}$ With the revaluation, Germany removed many of the border taxes and special reserve requirements on foreign deposits in German banks that had been used to limit capital in-
18See Salant et.al. (1963)

19See ERP (1964), p. 139.

20ibid.

${ }^{21}$ See ERP (1964), p. 143.

22See IMF (1964), p. 28 23!bid., p. 32

${ }^{24}$ The mark had been revalued by 5 percent in 1961 . Solomon (1982), p. 162, reports the May 1969 statement given by a German official that the decision to not revalue was "final, unequivocal and for eternity." This is one of many strong denials during the period. 
flows to Germany. ${ }^{25}$ After the revaluation German prices rose more slowly than U.S. prices.

The experience of the late 1960s had a lasting effect on German monetary policy. After the mark re-entered a fixed exchange rate system with the principal continental European countries in the late 1970s, Germany revalued more frequently to avoid inflation and exchange controls. In the late 1960s, however, revaluation was delayed too long and was much too small to offset the effects of inflationary U.S.

monetary policy. ${ }^{26}$

While urging German revaluation, the United States increased money growth in 1968. After the German revaluation, the Federal Reserve shifted to a more restrictive policy, raising the Federal funds rate (figure $2 \mathrm{a}$ ) and slowing the growth of the monetary base. The sharp contraction in the growth of the base was followed by the start of a recession in the fourth quarter. The reduction in money growth, the increase in U.S. real rates of interest, and the recession helped to shift the current account balance toward surplus. By the middle of 1970 the quar. terly balance had returned to a level not reached since the latter part of 1963 .

\section{Proposals 10 Increase Liguidily}

"Adjustment" was one of a triad of topics discussed at numerous official and unofficial inter. national meetings. The other topics were "li. quidity" and "confidence." Liquidity received the most attention.

proposals for additional liquidity differed. The French position was one extreme, the U.S. position the other. The International Monetary Fund took a position close to that of the United States. Positions did not remain fixed, but they were never fully reconciled. ${ }^{27}$

The U.S. position was that a new reserve asset was needed to supplement the stock of gold and dollars. Sales from official holdings in the London gold market had reduced official hold-

25 See Solomon (1982), p. 164 .

${ }^{26}$ Other parity changes during the second half of the $1960 \mathrm{~s}$ include an 11.1 percent devaluation of the French franc in 1968 and a 14.3 percent devaluation of the British pound in 1967 . Many of the stering bloc devalued following Britain.

${ }^{27}$ Solomon (1982) gives a thorough account of the discus. sions, proposals and the meetings of various official groups. Solomon was a senior civil servant at the Federal Reserve with responsibility for international finance and an acive particlpant or observer at most of the discussions. ings during the middle 1960s, and dollar liabilities had continued to rise relative to the U.S, gold stock. The United States argued that it expected to bring its payment deficits to an end. When this happened, the world trading system would lack an adequate supply of reserves to finance future demand for reserve assets at the fixed gold price. Hence, the United States favored creation of a new reserve asset that could be increased with world trade or world demand for reserves.

This argument is, at best, incomplete. If the United States had a payments surplus, other countries would have deficits. The United States could add to reserves by buying other stable currencies, just as these countries bought dollars. The Economic Report recognizes that this argument is correct. Even if each country was in balance, the United States could buy foreign exchange for dollars to augment its reserves. ${ }^{28}$

The IMF combined the liquidity and adjustment issues. They argued that the creation of a new reserve asset and additional reserves reduced the need for deficit countries to adjust and increased the pressure on surplus countries to adjust. ${ }^{29}$ This is, of course, an argument for inflation as a solution to the adjustment problem for the deficit countries and revaluation as the remedy for the surplus countries. This program was asymmetric: world inflation would increase but not decline.

Data in the IMF report, however, do not show a general problem of liquidity at the time. The IMF used reserves as a percentage of imports to measure liquidity - on the usual assumptions that reserves are used to finance imbalances and imbalances increase with trade. The data show that there was no general shortage of liquidity on this measure. The problem was limited mainly to the United States and the United Kingdom. Table 2 shows these data. Reserves in* clude gold, foreign exchange and reserve position at the IMF.
${ }^{28}$ See Economic Report (1964). p. 145.

${ }^{29}$ See IMF (1966), p. 10. 


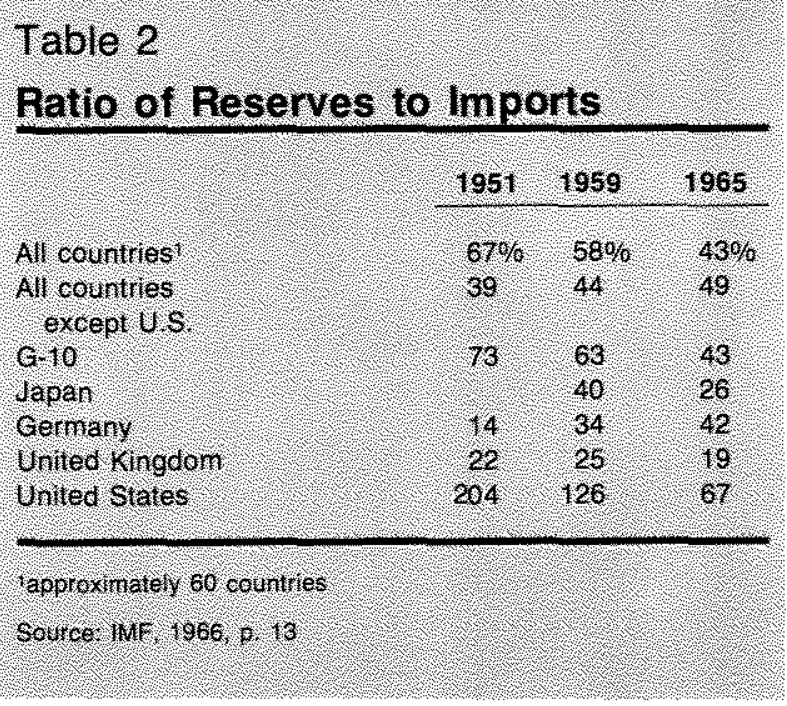

The United States aside, world reserves were a larger percentage of imports in 1965 than in 1951 and not very different in 1965 than in 1959. The IMF notes that the ratio of reserves to imports fluctuated around a constant value. ${ }^{30}$ Among major countries, only the United Kingdom shows a relatively low ratio. For many countries, the ratio had converged to 40 to 50 percent. $^{31}$

The French complained about the special role of the dollar, the opportunity given to the United States to use domestic inflation to acquire foreign assets (at fixed exchange rates), and what they called U.S. hegemony. As a first step, they proposed to limit the size of U.S. payments deficits that other countries were obligated to finance, but they also sought a permanent arrangement under which reserve assets would be tied to gold. Later, they urged an in. crease in the price of gold. Jacques Rueff (1967) proposed a doubling of the price of gold accompanied by commitments by the United States and the United Kingdom to use part of the profit from revaluation to retire some of the dollar and sterling reserves held by foreign central banks. $^{32}$

In its official proposals, the French government did not at first go as far as Rueff in favoring an increase in the gold price. Nor did it insist on a return to the gold standard. It favored a larger

30See IMF (1966), p. 12

31bid., p. 14.

32Rueff was Economic Adviser to President DeGaulle. 33 See Solomon (1982), p. 73. role for gold, restrictions on the financing of U.S. deficits, and a refunding of the sterling and dollar balances, particularly the latter. ${ }^{33}$ In early discussions, France wanted to circumvent the IMF by creating a reserve asset for use by the Group of 10 . The new asset would have a permanently fixed relation to gold. The effect of this proposal was to increase the effective gold stock and to devalue the dollar against gold.

The French proposal was not accepted. The alternative chosen was to create a new asset. In September 1967, at the Rio de Janeiro meeting of the International Monetary Fund, agreement was reached on the general principles governing creation of a supplementary reserve asset called Special Drawing Rights (SDRs). The new asset was to be a supplement to gold and dollars. The United States was not required to redeem dollar balances, and the gold price remained fixed. SDRs could be issued only if an 85 percent majority approved, and they would be held only by official holders, central banks and international monetary institutions. Finally, in July 1969, the amendments to the IMF agreement were ratified by a sufficient number of members to come into effect. At the Rio meeting of the IMF, the first allocations were agreed to but not issued.

In the IMF view, reserves were "less than adequate." 34 The report acknowledged that "the signals were conflicting., ${ }^{\prime \prime 35}$ The principal argu* ment for more reserves is that non-tariff barriers, aid-tying, domestic preference and other trade restrictions had increased. At the time, no argument was made about the relation of reserves to trade or imbalances. And the argument about trade restrictions makes no effort to link trade restrictions to the liquidity problem. In fact, the restrictions continued in many countries after 1973.

SDRs were issued in 1970-72 and again in 1979-81. The 1970 issue added $\$ 3.1$ billion to reserves. In the same year foreign exchange reserves increased by $\$ 14$ billion, and total reserves reached $\$ 91$ billion, a 50 percent increase for the decade and a 22 percent increase for $19700^{36}$ In total, 21.4 billion SDRs (valued in SDR units) were issued through 1985 when new
${ }^{34}$ See IMF (1969), p. 27.

35lbid., p. 26.

${ }^{36}$ See IMF (1971), p. 19. 
issues ceased. SDRs never became an important means of settlement. By the time the agreement to create SDRs had been reached, the Bretton Woods system was in its last days.

It seems doubtful that the SDR would have become a dominant medium of exchange or store of international reserves if the fixed exchange rate system had survived. The SDR was a specialized money but did not dominate alternatives as a means of payment or store of value. Gold is an established store of value with a long history. SDRs had to compete also with the dollar and later the mark, the yen and other currencies as a reserve asset. Balances held in each of these assets earn interest. At first, SDR balances did not earn interest, so they were less attractive than balances held in short-term government securities of the principal countries. There was no source of revenue or earnings; interest payments could only be made by creating additional SDRs.

After 1973, flexible exchange rates removed any need for a large stock of reserves for settling balances between principal countries, although countries continued to accumulate reserves and to intervene in the foreign exchange markets. The SDR could not be held by private wealthowners, so it could not be used for intervention. Further, the introduction of SDRs did not adjust relative prices or real exchange rates. Failure to solve the adjustment problem meant that the major effort to sustain the system by producing a supplementary reserve asset was largely wasted effort.

Additional creation of SDRs in 1972 was again divorced from events. World reserves (net of gold) had doubled in two years (from SDR 56 in 1970 to SDR 112 in 1972). Reserves in relation to imports were at the highest level in the postwar period before or after; countries held reserves equal to more than 14 weeks of imports at the end of 1972. In 1963, at about the time that the discussion of additional reserves began, the ratio was equal to nine weeks. In the same period, 1963-72, total reserves (net of gold) quadrupled in nominal value. ${ }^{37}$

The French were correct on two points that U.S. officials (and others) refused to acknowledge. First, the Bretton Woods system based on the dollar permitted the United States to export
Table 3

Rates of Growth of Money, 1969-71. Selected Countries

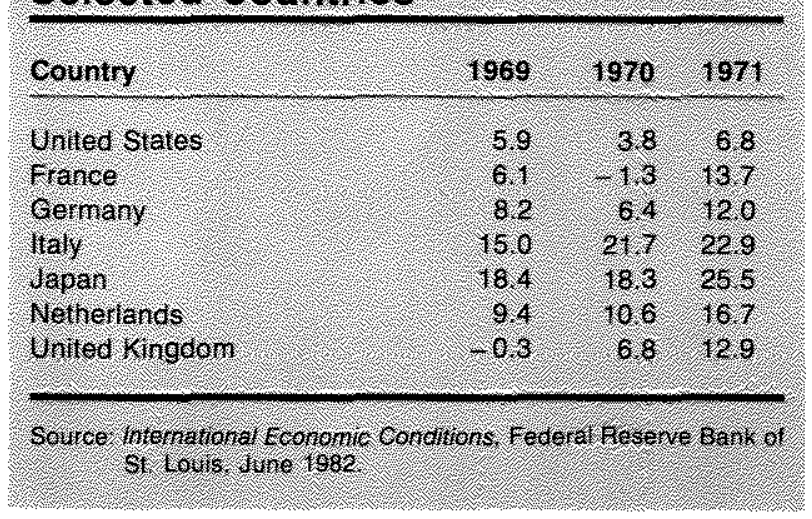

inflation to the rest of the world. Countries were obligated to buy all dollars offered at a fixed price. Sterilization of the inflow could be successful for short-periods, but as Switzerland, Germany and others discovered at the time, the fixed exchange rate gave speculators an opportunity to invest in one-way gambles with low risk and relatively high expected return. The Swiss franc or the mark were unlikely to depreciate, more likely to appreciate. Investors and speculators knew this. Hence, flows into these currencies became difficult to curtail.

Table 3 shows the pattern of money growth for a sample of countries. Many countries show a decline in money growth from 1969 to 1970 and all show a rise from 1970 to 1971, corresponding to the pattern in the United States, as France claimed. The size of the changes differs by country. All countries did not have the same trade pattern, so they did not receive the same proportional increase in base money. Some sterilized part of the increase for a time, and some countries adopted controls to reduce the inflow. In the winter of 1971, Germany allowed its exchange rate to appreciate relative to the dollar, slowing the inflow of dollars. This action recognized, as France has insisted, that countries could not prevent inflation while maintaining their dollar parities.

The second point on which the French position was correct was that revaluation of gold would solve the liquidity problem. Their various proposals would have devalued the dollar against 
other currencies, thereby providing the addition to the stock of reserves that the SDR was supposed to provide. French proposals did not limit future changes in the price of gold, so they are open to the charge that expectations of future devaluation would lead to a run on the dollar once it had been devalued. Much earlier, Keynes (1923) had proposed a type of commodity standard in which gold served as a medium of exchanges. In this proposal, the gold price was tied to an index of commodity prices. Had a scheme of this kind been adopted, it seems likely that the Bretton Woods system would have lasted longer.

A devaluation of the doliar against gold, with other currency values unchanged, would have removed the liquidity problem in the $1960 \mathrm{~s}$. At the end of 1968, the U.S. price level was approximately 2-1/2 times the 1929 level. If the gold price had been raised proportionally from its 1929 value $(\$ 20.67)$, the 1968 price would have been approximately $\$ 52$. At that price, the U.S. gold reserve would have been $\$ 17.6$ billion, $\$ 1.6$ billion more than U.S. liabilities to central banks and governments.

Although adjustments in the price of gold would have extended the life of the Bretton Woods system, it is unclear whether the system would have survived for more than a few additional years without some restriction on U.S. monetary policy, restrictions that the United States was unlikely to accept. Inflationary policies in the United States continued through the 1970 s with only brief interruptions. Countries that chose to lower inflation in the 1970 s would have had to leave the system. Further, inflation was not the only problem. The oil shocks of 1974 and 1979 changed the terms of trade, requiring changes in exchange rates that Bretton Woods system found difficult to accommodate. At best, devaluation of the dollar against gold would have corrected for differences in productivity growth and changing costs of production between the United States and the principal surplus countries, Germany and Japan. U.S. devaluation and the oil shocks would have changed the relative positions of other countries. Some would have found their trade balances in persistent deficit, requiring adjustment of their relative prices and costs or devaluations and revaluations of bilateral and multilateral
Fates, adjustments that were difficult to make and which would, in turn, have required further adjustments.

There is a plausible case to be made on the other side-that devaluation of the dollar would have prolonged the life of the Bretton Woods system. The key assumption is that the oil producing countries raised the price of oil in re. sponse to the decline in their real incomes after the dollar floated. A modest devaluation to a new fixed parity might have avoided the first oil shock. If so, the mistaken policies in the United States, attempting to offset the real effects of the oil price rise by inflation, would have been avoided. Inflation would have been lower and U.S. nominal gold reserves larger. It seems unlikely, however, that other countries would have accepted a U.S. policy of inflation and repeated, periodic devaluation against gold. Without a lower rate of inflation in the United States, the Bretton Woods system would have failed sooner or later.

Nevertheless, the French proposal was a straightforward solution to the liquidity problem of the 1960s. It would have resolved the ilquidity problem at least for a time but would not have resolved the more difficult "adjustment problems" arising from changes in countries' prices, productivity, and costs of production. This was not the main reason for rejecting the proposal, however. Representatives of the governments and central banks claimed that any change in the $\$ 35$ gold price or devaluation by a reserve currency country would damage "confidence."

\section{Confidenes}

Throughout the 1960 s, there were concerns about whether the United States could avoid default on its obligation to convert dollars into gold at the $\$ 35$ gold price. Expressions of lack of confidence in the dollar often brought forth speeches by Presidents, Treasury secretaries and others to bolster "confidence." Words were not the only response. Actions were taken to strengthen or restore confidence.

The dollar and, to a lesser extent, the pound had a special role in the Bretton Woods system. They were "reserve currencies." ${ }^{38}$ Central banks held dollar or pound securities as reserves in

38The use of reserve currencies was not part of the Bretton Woods plan. Britain's role evolved from its prewar position and the holding of stering balances by countries in the sterling bloc. The dollar's role evolved from the dollar bloc and the unique position of the United States in the early postwar years. 
place of gold to earn interest on their balances. Devaluation reduces the real value of these reserves, so anticipation of a devaluation could lead to a run on the dollar on the pound. Once total claims against the reserve currencies ex. ceeded the gold reserves held by the United States and Britain, discussion of the confidence problem intensified.

The first evidence of a lack of confidence in the dollar was a temporary rise in the gold price in 1960. In October, the gold price on the London market moved above the official intervention price, $\$ 35.20$ an ounce. Speculators said that the market was concerned about the possin ble election of John F. Kennedy as president and the continued capital outflow from the United States. Kennedy's talk of "getting the economy moving" may have seemed inflationary. To counter these concerns, Kennedy made a strong commitment to maintain the gold value of the dollar, and the Eisenhower administration took the first steps (discussed above) to reduce the U.S. payments deficit.

The temporary increase in the London gold price reflected both a rising demand for gold from European central banks and private holders and a refusal by the United States to supply gold to the market. The London gold price was set to clear trading. To maintain the price within its band, the Bank of England bought or sold gold for dollars, replacing the dollars or gold in an exchange with the U.S. Treasury. In October 1960, the Treasury appeared unwilling to restore the Bank's gold holdings, so the Bank refused to buy dollars for gold. With the residual buyer of dollars inactive, actual and prospective supply was reduced; the price of gold rose to $\$ 40$ on October 27 . The Treasury resumed sales, and the price returned to $\$ 35$.

Two changes were introduced as a result of this experience. European central banks agreed not to buy gold on the London market if the price rose above the U.S. price plus shipping cost, $\$ 35.20$. In October 1961, seven European governments and the United States created a gold pool. Each member of the pool agreed to let the Bank of England buy and sell for the group, and each received a pro-rata share of any gold purchases and supplied a share of gold

\footnotetext{
39 See Schwartz (1987), p. 342.
}

40 Unit labor costs (ULC) are available for Canada, Japan Germany and the United Kingdom from 1963 to date. The index of foreign ULC is based on these countries. All data sales. During the years that the pool functioned, member countries sold gold worth (net) $\$ 2.5$ billion on the London market. The U.S. share was $\$ 1.6$ billion ${ }^{39}$ As shown in figure 1, during approximately the same period, 1961-67, U.S. gold reserves fell more than $\$ 5$ billion, the difference reflecting direct sales from the U.S. gold stock. But, as noted earlier, during the same period, the countries in the $\mathrm{G} \cdot 10$, and especially France, added more than 100 million ounces ( $\$ 3.5$ billion) to their official gold reserves. The amount added by the G.10 represents 97 percent of the sales by the United States outside the gold pool. These data suggest that the pool did not function as intended; the G-10 replaced their sales from U.S. stocks.

The years 1962-64 saw a substantial increase in the U.S. current account surplus and reduction in the payments imbalance. The gold outflow, figure 1, slowed. Part of the improvement resulted from the restrictions on military and other purchases abroad, but part was the result of rising exports, achieved despite the relatively robust economic expansion in 1963 and 1964.

Figure 4 shows quarterly data on the current account balance (in billion of dollars) from 1960 to the end of the Bretton Woods system. After the increase in the surplus, to 1964 , there is a steady decline interrupted by the recession of 1969-70. The temporary surplus of 1970 was soon replaced by a deficit that eliminated the effects of the surplus; the observations for 1972 are on a straight line fitted to the data for the second half of the $1960 \mathrm{~s}$.

To slow the growth of dollar reserves abroad, the United States had to reverse the current account balance sufficiently to cover private investment abroad, transfers, and other capital flows, not in any particular year, but over time. By this standard, policy can be said to have failed to offset the negative trend in the current account balance after 1964 .

One reason for the rising surplus in the U.S. current account balance in the early 1960s is that foreign costs rose relative to U.S. costs. Figure 5 shows the unit labor costs (ULC) for the United States relative to unit labor costs abroad.$^{40}$ The ULC ratio reaches a trough in are from OECD, Main Economic Indicators, Historical Statistics, 1990. The weights are Federal Reserve trade weights normalized to sum to unity. 1985 is taken as the base year for United States and the trade weighted ULC. 


\section{Figure 4 Current Account Balance}

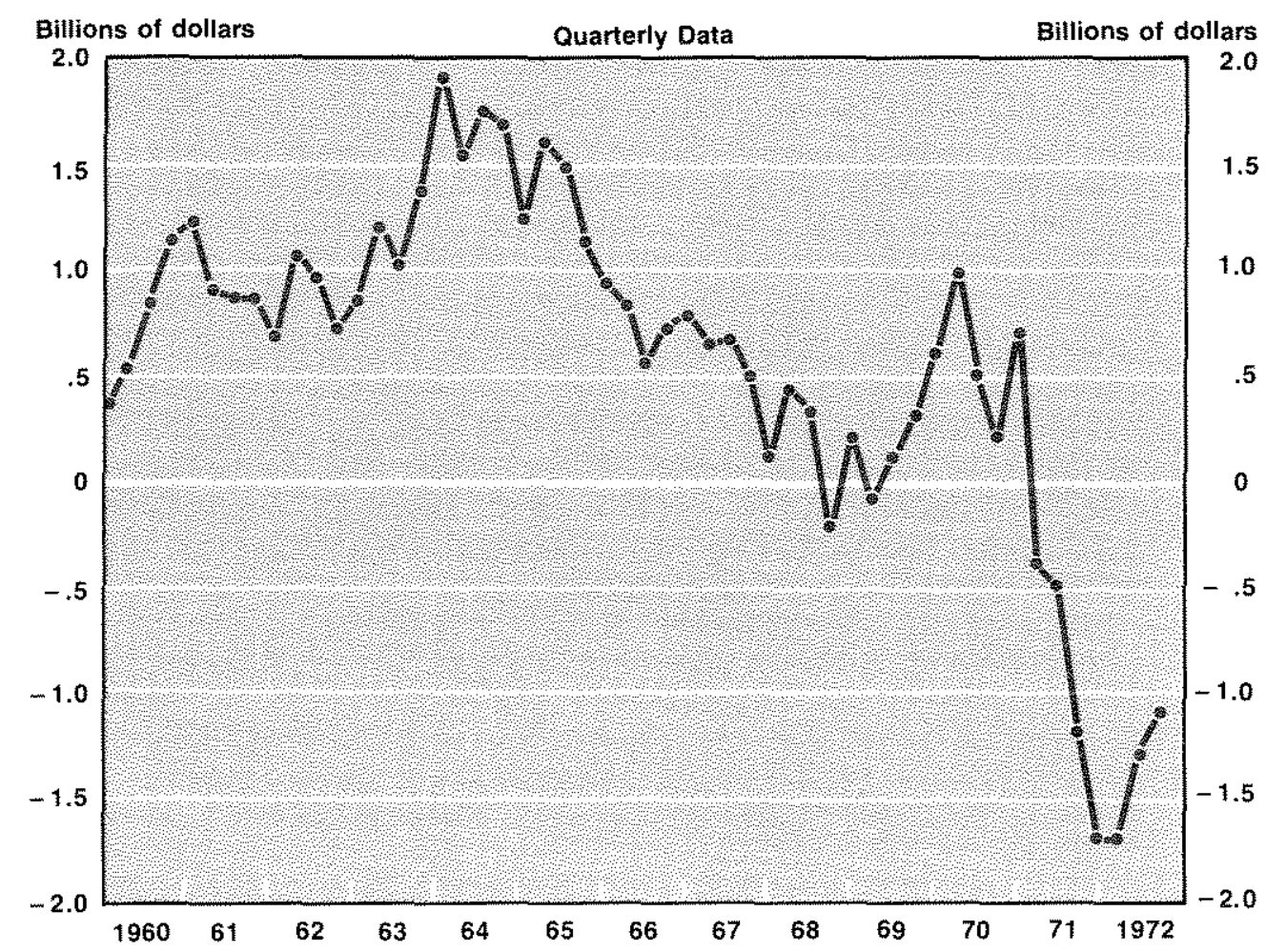

third quarter 1963, then reverses to reach a local peak in fourth quarter 1968. The current account (figure 4) has a similar movement; although its local peak is a bit earlier, the balance remains relatively higher until second quarter 1965. The trough of the current account is also in second quarter 1968 . The next swing continues the negative relation. The current account rises until early 1970 while the ULC ratio falls. Thereafter, the two charts move together, falling until the end of Bretton Woods. A sharp decline in the ULC ratio accompanied the decine in the trade balance until 1972 .

The comparison suggests that until 1970 or 1971, changes in the current account balance are consistent with the movements of relative costs. After 1970 the situation changed. The fall in the current account is not the result of a worsening of the competitive position of the United States as reflected in relative costs of production. The fall in relative costs may have continued to increase the current account balance, but their influence was more than offset by pressures in the opposite direction.

One possible explanation of the change in $1970-71$ is that relative real rates of return to capital moved against the dollar. Such movements should be reflected in relative real rates of interest. Figure 6 shows the ratio of the ex post U.S. real interest rate to a trade weighted average of real interest rates using Federal Reserve trade weights. ${ }^{41}$ The figure shows the
41The Federal Reserve uses shares of world trade to set individual country weights. The real interest rate index for foreign countries is based on Treasury bills for Canada and the United Kingdom and call money rates for Ger" many and Japan. The Federal Reserve trade weights are standardized for the four countries to sum to unity. Inftation is measured by the consumer price index for each country. The ratio shown uses three-month moving averages (not centered) for both series. 


\section{Figure 5}

\section{Ratio of U.S. Unit Labor Costs to Trade-Weighted Unit Labor Costs}

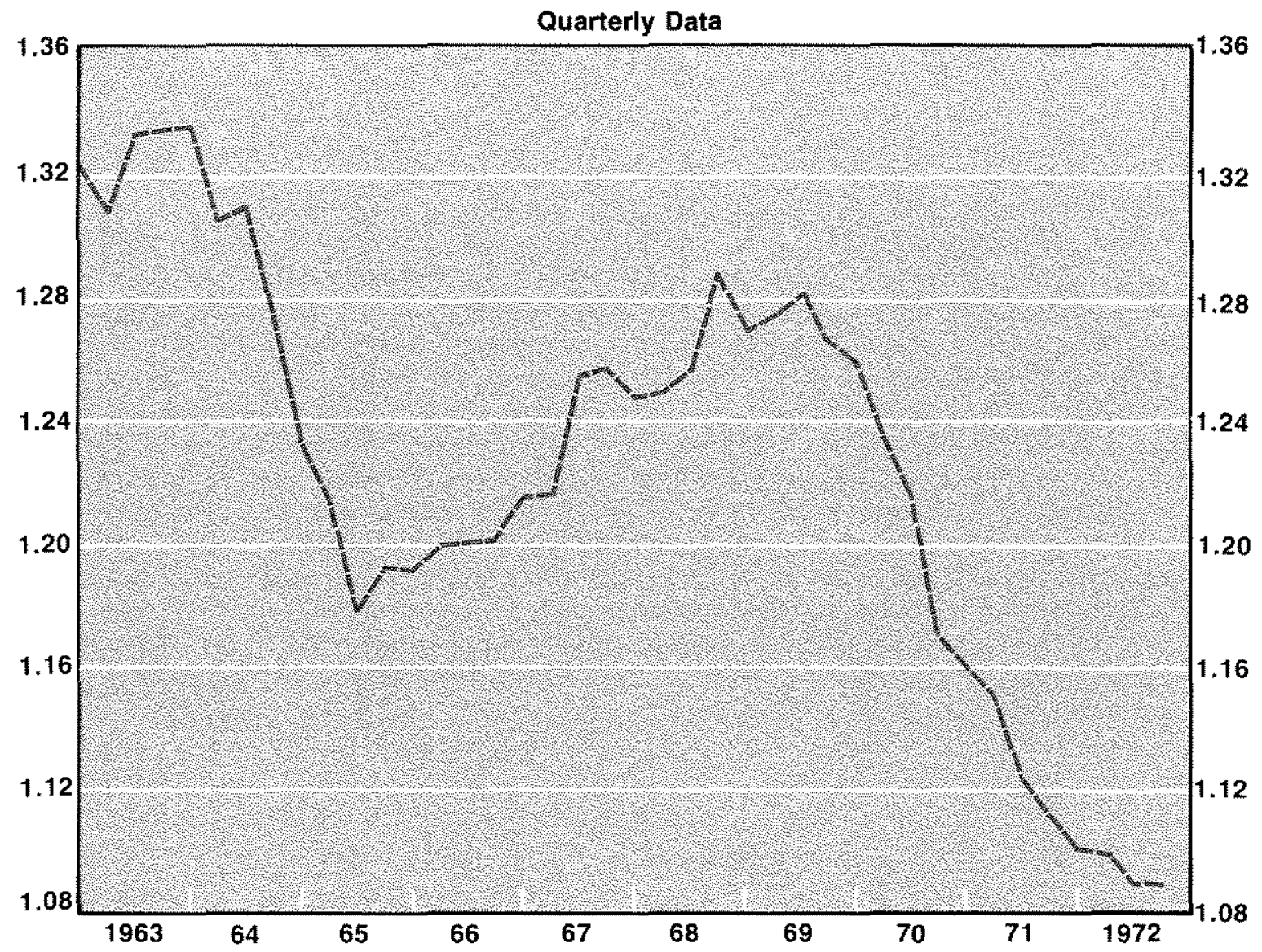

ratio of a three-month, non-centered, moving average of the U.S. short-term interest rate to a three-month moving average of short-term rates abroad. All rates have been adjusted for inflation in the particular country.

These data show that from 1960 to 1969 , U.S. real interest rates rose on average relative to rates abroad. The sharp rise in U.S. rates from 1962 to 1964 contributed to the reduction in the net capital outflow and is reflected in the rise in current account surplus. The movement of relative interest rates, on average, reinforced the effect of falling relative costs of production during this brief period. After 1965, the relative rate of interest continued to rise, but the rise was too small to reverse the falling current account balance. And the increase in relative interest rates in the United States was apparently too small to prevent the very large capital outflow in that period. The path of relative interest rates does not explain the collapse of the current account balance and the large capital outflow in the early 1970 s.

Relative interest rates give little evidence of a growing lack of confidence in the dollar in the late 1960 s. A flight from the dollar would have pushed real U.S. interest rates above rates in world markets to compensate for the risk of 


\section{Figure 6 \\ Ratio of U.S. Real Interest Rate to Trade-Weighted Real Interest Rate}

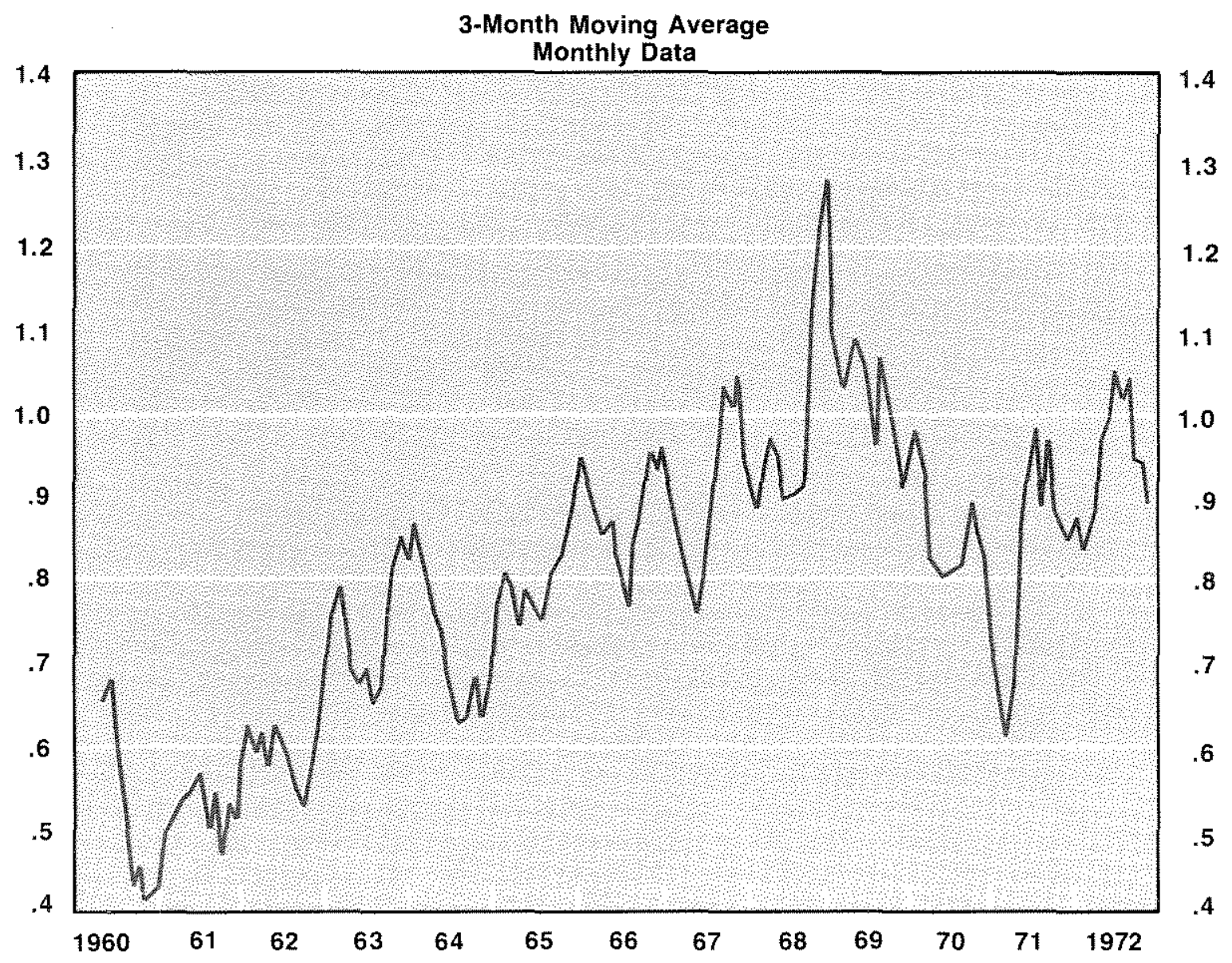

devaluation and a run on the dollar. With few exceptions real rates in the United States were below rates abroad, on average about 10 percent below from 1966 to 1972 . There is no evidence of a sustained rise in U.S. rates. The Federal Reserve pumped out monetary base to hold down interest rates. The rest of the world absorbed the dollar outflow with little change in real U.S. rates relative to rates abroad. The main exception is a spike in 1968-69 that mainly reflects a decline in the weighted average of real rates abroad.

The data on relative real rates of interest suggest that the Federal Reserve made little effort to slow or stop the capital flow. During the win- ter of 1971 relative real rates in the United States fell until March along with U.S. real rates, despite the large dollar outflow. The rise in relative rates in the spring and summer reflects both a decline in foreign rates and a rise in U.S. rates.

The gold and foreign exchange markets also give little evidence of a lack of confidence leading to a flight from the dollar during the 1960s. An exception is the winter of 1968 when the gold price rose and the two-tier market began. By 1969 , the gold price in the free London mar. ket had fallen back to $\$ 35.2$ per ounce. The same cannot be said for the other reserve cur. rency, the pound sterling. By 1964, the pound was subject to market pressure to devalue rela- 
tive to gold and the dollar. Repeated attempts to reduce the pressure each succeeded for a short time, then failed. Finally in November 1967, Britain devalued by 14.3 percent (from $\$ 2.80$ to $\$ 2.40$ ). Members of the old sterling bloc followed.

Pressure to devalue sterling occurred against a worsening problem of U.S. domestic inflation and a deteriorating relative cost position (figure 5). The Johnson administration's main efforts to slow price and wage increases were limited to exhortation (jawboning). These efforts extended to interest rates. With short-term interest rates fixed by the Federal Reserve (figure 2a), rising demand for goods and services and anticipations of higher inflation encouraged increased borrowing and higher money growth. As shown in figure $2 b$, the annual growth of the monetary base rose in 1965. Base growth reached the highest rate experienced in the postwar years to that time. Efforts to hold down rates paid on time deposits under Regulation $\mathrm{Q}$ ceilings added to the pressure on the banks. Depositors drew on balances to purchase securities in the open markets at home or abroad.

Early in December 1965, the Federal Reserve raised the discount rate from 4 to $4-1 / 2$ percent and raised ceiling rates on time deposits. Although president Johnson criticized the change publicly, the higher rates remained in effect. As is often the case, however, the increase was too little and too late. Annual growth of the monetary base from the same month a year earlier did not decline until the second half of 1966, as shown in figure $2 \mathrm{~b}$. Inflation rose early in 1966. U.S. interest rates, after adjusting for inflation, fell relative to foreign rates (figure 6). Declines in relative unit labor costs and relative consumer prices ended. Reflecting these changes, the nom. inal current account balance plunged in the five quarters following the December 1965 decision, eliminating most of the increase achieved in the previous six years.

The Federal Reserve made a short-lived effort to slow the inflation in 1966. The federal funds rate rose and the growth of the monetary base contracted in the second half of the year. Responding to the less inflationary policy, sensitive measures of prices, such as the producer price index, reversed direction of change, falling from

42 See Solomon (1982), p. 102.

43 Haberler (1965) was one of the first to emphasize the greater importance of the adjustment problem relative to the local peak in third quarter 1966 to a local trough in second quarter 1967. A six-month aver. age of consumer prices fell from a 4 percent annual rate in January 1966 to 1.3 percent in February 1967. Given the upward bias in consumer prices, resulting from the heavy weight on service prices (that are not adjusted for productivity and quality changes in inputs and outputs), it appears that the Federal Reserve had stopped the inflation. But, as figures $2 a$ and $2 b$ show, the Federal Reserve did not continue the policy. Federal funds remained at 4 percent for most of 1967 despite clear evidence of recovery.

By early 1968, consumer prices were rising at a 3 to 4 percent annual rate and, more impor. tantly for the payments problem, rising relative to a weighted average of foreign prices. Relative unit labor costs rose sharply. The effects of changes in relative costs and prices on the U.S. payments position were partially hidden at first by a capital inflow from Europe; U.S. banks had began borrowing from the Eurodollar market. In part, this reflected the pise in relative rates of interest by 0.25 in the United States ffigure 6), in part efforts to circumvent ceilings on time deposits including, at the time, all certificates of deposit (regardless of denomination). The result was a payments surplus in 1966 , the first since 1957, and repayment of earlier Treasury and Federal Reserve borrowing from central banks and governments. ${ }^{42}$

Confidence in the administration's ability to maintain convertibility into gold or avoid devaluation reached a temporary low early in 1968 . The immediate problem began with a run on gold when Britain devalued. The gold pool sold $\$ 800$ million in November 1967 . The run subsided in January, following the announcement that President Johnson had placed new controls on foreign investment by businesses, banks and financial institutions.

Demands for gold rose again in March. Rumors that the gold pool would end and the low cost of speculating against a price that could fall very little encouraged renewed speculation. After sales of $\$ 400$ million on March 14, the London gold pool closed the next day. That marked the end of the gold pool. The market did not reopen until April. When it did, central banks no the liquidity problem, but neither his remonstrance nor others had much effect on official proposals. See also Friedman (1953). 
longer supported the market price. There was now a two-tier market. Private transactors could buy and sell at the market determined price, although the 1934 ban on U.S. citizens' ownership of gold remained. Transactions between central banks were placed outside the market and continued at the $\$ 35$ price. Also, the governments agreed that gold would not be sold by the members of the former pool to replace any central bank sales to the private market.

The central bank governors' communique' put a positive interpretation on their announcement, repeated their intention to maintain existing parities, and referred to the then forthcoming agreement to establish the SDR. It made no mention of adjustment of parities. ${ }^{43}$ The central banks agreed to "no longer supply gold to the London gold market or any other gold market," but they hedged their statement to retain the possibility of buying gold. ${ }^{44}$ The two-tier agree. ment remained in effect until November 1973.

The free market gold price went to $\$ 38$ per ounce, suggesting that the market would have been satisfied by 10 to 15 percent devaluation of the dollar. For the rest of the year, the free market price remained between $\$ 38$ and $\$ 43$. Then the price fell back to $\$ 35$ to absorb an increased supply of South African gold. ${ }^{45}$

For the year 1968 as a whole, the United States had a surplus in the balance of payments. The reason is that banks continued to borrow in the Eurodollar market and, following the Soviet invasion of Czechoslovakia, foreign investors purchased U.S. assets. ${ }^{46}$ These decisions and events produced a payments surplus in 1968 despite a further decline of $\$ 2$ billion to $\$ 0.6$ billion in the current account surplus.

One lasting effect of the winter's events was the elimination of the gold reserve requirement for Federal Reserve notes. On March 12, Congress abolished the 25 percent gold reserve behind Federal Reserve notes. The legislation removed one of the last links between gold and the dollar in the original Federal Reserve Act. The initial requirement ratios, or backing, for bank reserves and currency had first been reduced, then eliminated for bank reserves and, finally, eliminated for currency. The stated purpose was to make the gold stock available to de- fend the $\$ 35$ price. In fact, central banks did not again convert dollars into gold until 1971 .

The two-tier system and the decision by central banks to refrain from converting dollars into gold had an unanticipated effect on the soon to be created SDRs. The United States had sponsored SDRs and urged their use as a substitute for gold in central bank reserves. Since central banks refrained from selling gold, and bought newly mined gold from South Africa and the Soviet Union, issues of SDRs served as a substitute for dollars in central bank reserves.

Looking back after the fact, it is surprising how small was the loss of confidence in the dollar as a reserve currency before 1971. Central banks and governments preferred to absorb dollars rather than revalue their currencies. Some private speculators purchased gold or other assets, but the purchases were not large enough to move the equilibrium gold price persistently above the fixed price until 1970 .

Meeting after meeting during the last five years of Bretton Woods mentioned the three problems: confidence, liquidity, and adjustment. Central bank governors, ministers and their staffs gave most of their attention to liquidity and then to confidence. Aside from a few relatively small changes in parities, little was done about adjustment. The attitude of the IMF is representative of the period. Their 1969 report mentions adjustment of par values, following the French devaluation. The discussion reached only one conclusion: the par value system should be retained. ${ }^{47}$

\section{THE RND OF TRETTON WOONS}

Concern about the rising budget deficit, the payments problem and inflation led Congress in June 1968 to accept the Johnson administration's proposed 10 percent income tax surcharge and, in return, to require the administration to reduce the growth of government spending. The response of the Federal Reserve was almost immediate; they reduced the federal funds rate in an attempt to mix easier monetary policy with tighter fiscal policy. Growth of the monetary base declined briefly, then rose to a 7 percent annual rate of increase (figure $2 \mathrm{~b}$ ). The six month average rate of increase of consumer
${ }_{44}^{4}$ See Solomon (1982), p. 122.

45lbid., p. 124.
46 lbid., p. 105.

${ }^{47}$ See IMF (1969), p. 32. 
prices rose at a 4 percent rate in 1968 but the annualized rate of increase was 6.5 percent at the end of the year.

U.S. consumer prices now began to rise relative to a trade weighted average of prices abroad (figure 3), reversing the trend decline of the early 1960s. Unit labor costs rose sharply relative to costs abroad (figure 5). The trade and payments position deteriorated; real net exports (1982 dollars) fell to $-\$ 30$ billion in 1968 and $-\$ 35$ billion in 1969 from $-\$ 17$ billion in 1967 after a $\$ 6$ billion surplus in 1964. As shown in Figure 4, the nominal current account balance continued to fall in 1968 , reversed briefly during the $1969-70$ recession, then resumed its decline.

The official settlements measure of the balance of payments shows the United States in surplus in 1968 and 1969 for the first time in the decade. ${ }^{48}$ This was misleading, much of it the proximate result of Regulation $Q$ ceilings on personal and corporate time deposits. As U.S. interest rates rose above the legal celling rates, commercial banks lost time deposits to the Euro. dollar market. ${ }^{49}$ The U.S. banks then borrowed in the Eurodollar market acquiring many of the deposits they had lost and some additional funds. The effect was to have a large inflow of shortterm capital, $\$ 4.3$ billion on the official settlements basis for the two years.

Interest rates fell during the 1970 recession, real rates declined on average relative to rates abroad, and the capital flow reversed with a vengeance. The official settlements deficit of $-\$ 9.8$ billion was by far the largest to that time. But this flow was soon dwarfed by the $-\$ 31$ billion outflow in the first three quarters of 1971.50

Figure 1 shows the surge in liabilities to foreign central banks and governments. These liabilities more than doubled to $\$ 50$ billion in 1970 , then rose another $\$ 11$ billion in 1971. The classic response to a capital outflow for a country on a fixed exchange rate is to raise interest rates and reduce money growth. The Federal Reserve did the opposite, the federal funds rate fell from a peak of 9 percent early in 1970 to

48The official settlements balance measures the change in reserve assets minus the change in short- ard long-term liabilities to foreign official institutions (central banks or in. ternational agencies).

49A Eurodollar is a dollar deposit liability of a European based bank, including European branches of U.S. banks. less than 4 percent the following year. Growth of the monetary base rose from 4 to 8 percent annual rate in the same period.

To any outside observer, it must have been clear that the United States did not intend to follow the classical rules or the policies of a country that intended to maintain a fixed ex. change rate. The run from the dollar began. Foreign central banks experienced large increases in dollar reserves. Germany added \$3.1 billion in the first six months of the year. Ger. man money growth rose from 6.4 percent in 1970 to 12.0 percent in 1971. German consumer prices, which had increased 1.8 percent in 1969 rose 5.3 percent in 1971 . Despite rigid exchange controls, Japan could not escape the direct ef fect of U.S. money growth through the trade account. Japan's reserves nearly tripled in the first nine months of 1971 , rising $\$ 8.6$ billion. The Japanese money stock $\left(\mathrm{M}_{1}\right)$ rose more than 25 percent in 1971. Other countries had qualitatively similar experience.

In 1969, after much delay, Germany had closed the foreign exchange market, allowed the mark to float, then revalued by 9.3 percent on October 24. Within two years, three major currencies-the British pound, the French franc and the German mark - had been forced to change exchange rates. ${ }^{51}$ The belief that economic stability required exchange rate stability began to erode.

The 1971 capital flow dwarfed previous ex perience. The U.S. deficit on capital account was almost $\$ 30$ billion for the full year 1971 and $\$ 42$ billion for the two years $1970-71$. of this amount, $\$ 40$ billion became dollar reserves of other countries. Japan and Germany accumulated $\$ 11$ billion each, more than half the total, and the United Kingdom acquired nearly $\$ 10$ billion. ${ }^{52}$ On May 5, seven European countries closed their foreign exchange markets. The German Finance Minister, Schiller, tried to persuade principal European countries to agree to a joint float, but France and Italy opposed. Four days later the mark and the Dutch guilder began to float. Switzerland revalued by 7 percent and Austria by 5 percent. ${ }^{53}$ Belgium, with a split ex-

soSee ERP (1972), p. 150.

5. France devalued by 11.1 percent on August 10, 1969

Canada floated its currency against gold in May 1970.

52See IMF (1972), p. 15

s3see Solomon (198?), p. 180. 
change rate, allowed the financial rate to float up. Early in August, faced with slow recovery from the recession, rising inflation, a persistent payments deficit, and fifteen months to election day, President Nixon decided to change economic policy. After meeting at Camp David on the weekend of August 13 to 15, he ended the fixed exchange rate system by suspending "temporarily the convertibility of the dollar into gold or other reserve assets."

The plan announced on August 15 included much more than the suspension of gold convertibility. Wages and prices were frozen for 90 days, allegedly to stop inflation then running at an annual rate of 3 percent for the six months ending in July. Tax credits to increase employment and investment were introduced to increase demands for output and labor and to reduce unemployment below 6 percent. A 10 percent surcharge was put on imports. ${ }^{54}$ By the end of August, all major currencies except the French franc floated against the dollar. ${ }^{55}$ The last remaining tie of the dollar to gold had been severed, at least temporarily.

Many of the changes announced on August 15 had been discussed for some time in advance. Chairman Burns of the Federal Reserve had advocated a price-wage policy for months. John Connolly, the secretary of the Treasury, favored strong action on trade and inflation. Stein reports that President Nixon and Connolly had agreed in the spring that they would impose price and wage controls if foreign demand for gold required them to close the gold window. ${ }^{56}$

The triggering event was renewed demands for gold from France and Britain. On August 8 , the press reported that France would ask for $\$ 191$ million in gold to make a scheduled repayment to the IMF. Later in the same week, on August 13, Britain also requested to exchange dollars for gold. The combined requests were

\footnotetext{
${ }_{54}$ More precisely, the surtax was used to raise import duties no higher than their statutory level from which tariff reductions had been made. For autos, the increase was, therefore, 6.5 percent (ERP, 1972, p. 148). Shultz and Dam (1977), p. 115 explain that the surcharge was to be used as a bargaining chip to keep other countries from following the U.S. devaluation against gold. U.S. policy was to devalue against goid and other currencies. The surcharge raised the price of U.S. imports, so devalued the dollar against other currencies until they agreed to a formal devaluation.

${ }^{55}$ France adopted a dual exchange rate with financial transactions at a floating rate.

56See Stein (1988), p. 166. Herben Stein was a member and later chairman of President Nixon's Council of Economic
}

small in comparison with the $\$ 12$ billion in crease in foreign holdings of dollars in the first nine months of 1971. Reports of demands for gold, however, generated fears of a run against the remaining U.S. gold reserve. ${ }^{57}$ President Nixon and his principal advisers met at Camp David on the weekend of August 13 to 15 to adopt the program based on the agreement reached by Nixon and Connolly in the spring. ${ }^{58}$

The earlier policy had been called "steady as you go." In fact, U.S. monetary policy had been far from steady in 1970-71. The federal funds rate was driven down from 9 percent early in 1970 to 3.7 percent in March 1971, then increased 5.3 percent in July. During the same period, growth of the monetary base increased from 4 percent to 8 percent. The effect, given policies abroad, was to lower U.S. short-term in terest rates relative to a trade-weighted average of rate abroad as shown in figure $6 .{ }^{59}$ The decline in relative real interest rates ended in March, then reversed but, by March, the dollar's fixed exchange rate was falling, reflecting growing fears of devaluation. These fears strengthened as currencies began to float or revalue against the dollar.

When asset markets opened on Monday August 16, traders greeted the new economic policy enthusiastically. U.S. interest rates fell and stock prices rose. Many of the foreign exchange markets abroad were closed, but in the United States and, later in markets overseas, the dollar depreciated against most currencies. An exception is the Canadian dollar which remained in a narrow band for the rest of the year. The Japanese yen was at the other extreme; it revalued by about 5 percent initially and rose 10 percent by the end of September despite much intervention by the Bank of Japan. Between December 1970 and July 1971, the trade weighted index of the real U.S. exchange rate

Advisers. The decision was told only to George Shultz, director of the Office of Management and Budget and Paul McCracken, chairman of the Council of Economic Advisers.

57See Shultz and Dam (1977), p. 110; Stein (1988), p. 166.

${ }^{58}$ Arthur Burns, chairman of the Board of Governors, participated in the meeting despite the independence of the Federal Reserve. Burns also participated in the administration's program as chairman of the Committee on Interest and Dividends.

${ }^{59}$ The locat peak in the relative rate is 1.27 in January 1969 . By March 1971 the relative rate reached 0.6 . 
Figure 7

\section{Dollar's Real Exchange Rate Index}

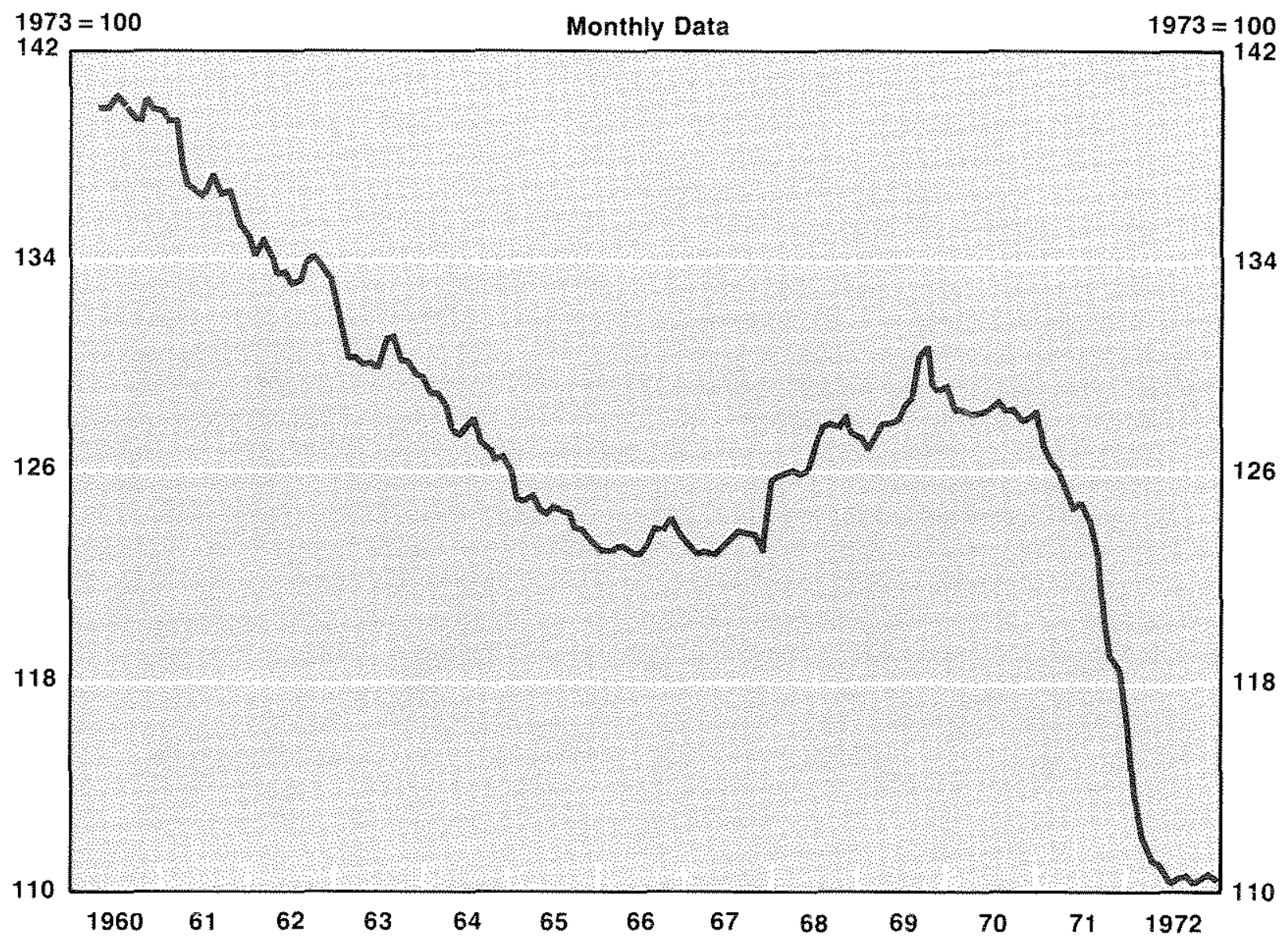

declined by approximately 3 percent; between July and the end of December 1971 the rate fell an additional 6.5 percent, so real devaluation for the year was approximately 9.4 percent.

Figure 7 shows the real exchange rate for the dollar against a trade-weighted basket of currencies using Federal Reserve woights. Since there are few parity changes prior to 1971 , the real exchange rate reflects mainly relative price changes. Hence, figure 7 for the most part duplicates figure 3 until 1971. Thereafter, the two charts differ; the real exchange rate reflects both the devaluation of the nominal exchange rate and the change in relative prices.

\section{What Ned?}

The price-wage freeze, the surtax on imports and the floating dollar were thought to be temporary measures. There is no evidence that the administration had developed a long-term program by August 15, but they began to do so.

The 1972 Economic Report summarizes some of their thinking by discussing three questions. Should realignment occur through market adjustment or negotiation? How large is the structural or permanent deficit? How should the reduction in the U.S. payments deficit be distributed among other trading countries? In practice, the distribution would be determined by the choice 
of exchange rates, so the issue was the size of relative revaluations against the dollar. ${ }^{60}$ Other countries, particularly France, wanted acknowl. edgment by the United States of its past infla: tion in the form of a devaluation against gold. Perhaps more important was the effect on country wealth. A devaluation by the United States raised the value of country gold stocks while a devaluation by other countries reduced the value of their dollar assets.

In the first nine months of 1971 the U.S. short-term capital outflow rose to $\$ 23$ billion, and the basic balance declined to $-\$ 10.2$ billion. At an annual rate, these outflows were equivalent to the entire short-term capital outflow for 1960-69. The outflow includes capital flight from the United States in anticipation of devaluation and a deteriorating current account balance. In part, deterioration reflected the worsening relation in U.S. prices relative to foreign prices. The ratio of U.S. consumer prices to trade weighted consumer prices in figure 3 shows an increase of four percentage points between 1966 and the end of 1970 .

Although Treasury Undersecretary Paul Volcker had testified in June that the basic imbalance was about $\$ 2.5$ to $\$ 3$ billion, Volcker now argued for a $\$ 13$ billion adjustment to reach equilibrium. ${ }^{61}$ The United States favored a period of free floating and offered to remove the 10 percent surcharge on imports if other countries would remove barriers to trade. Instead central banks intervened, and governments imposed exchange controls. Exchange rates were not permitted to adjust freely; new rates were negotiated.

\section{The Smithsoning Agreement}

In December, finance ministers and central bank governors met at the Smithsonian Institution in Washington to agree on a new set of exchange rates. Gold was repriced at $\$ 38$ per ounce, and bands on exchange rates were raised from 1 percent to 2.25 percent of central rates. The United States eliminated the $10 \mathrm{per}$ cent surcharge on imports, and the principal countries agreed to discuss reductions of trade barriers. ${ }^{62}$
The agreement on devaluation of the dollar against gold raised, or more accurately, continued a problem. The official gold price remained below the open market price that had now reached $\$ 42$. Central banks, therefore, had an incentive to convert dollars into gold and sell the gold on the open market. The "solution" was to raise the official price but not require the dollas to be convertible into gold!

The new exchange rates revalued the mark by 13.6 percent against the dollar, the yen by 16.9 percent the pound and the French franc by 8.6 percent, and most other European currencies by 7.5 to 11.6 percent. The Federal Reserve's calculation showed a trade weighted devaluation of the dollar of 6.5 percent against all currencies and 10 percent against the cur. rencies of the Group of 10 . The devaluation was estimated to produce an $\$ 8$ bilion swing in the U.S. trade balance in two to three years. ${ }^{63}$ The IMF estimated the dollar devaluation as 7.9 percent of its former par value. ${ }^{64}$ The effect of all the parity changes was to raise the world import prices by about 7.5 percent. 65

Prior to the agreement, inflexibility and lack of an adjustment mechanism had been major problems. Surplus countries had been reluctant to revalue because of the effects of their exports on domestic employment. The United States had been unwilling to devalue against gold. Many countries had relied on exchange controls to strengthen their currencies.

The Smithsonian agreement took two steps to improve adjustment. The gold price changed, opening the possibility of further changes, and the dollar was devalued against the leading currencies. In addition, cross rates of exchange were altered to reflect, partially, the changes in the world financial system. Also, the 2-1/4 percent band on exchange rates permitted divergence of up to 4.5 percent. But, nothing was done to provide an orderly procedure for changing parities when there were persistent deficits or surpluses. The system remained relatively inflexible and poorly designed for the event which it soon faced.
60See ERP (1972), p. 149.

61See Solomon (1982), p. 192-93; ERP (1972), p. 154. The $\$ 13$ bilion included a $\$ 6$ billion surplus to provite for lending to developing countries.

${ }^{62}$ Secretary Connally's initial position included renegotiation of defense costs, but this issue was dropped. The discus- sion of trade barriers produced very few changes.

(Solomon, 1982), p. 191.

635ee Solomon (1982), p. 211

64See IMF (1972), p. 38.

6s jbid., p. 22. 
President Nixon called the agreement "the most significant monetary agreement in the history of the world." ${ }^{\text {"6e }}$ In fact, it was a modest agreement that lasted less than fifteen months. Within a few months stresses reappeared in the international monetary system. In June, Britain decided to let the pound float. Within a month 17 members of the sterling bloc followed. In the same month, Germany imposed controls on capital inflows for the first time since the 1950s. ${ }^{67}$

The underlying problem was that U.S. policy remained inconsistent with maintenance of a fixed exchange rate system. Despite the price controls introduced in August 1971, the reported rate of change in consumer prices in 1972 was only 1 percent lower than in 1971. More importantly, the future did not look promising. The Federal Reserve made no effort to restrict money growth. Despite a surge in aggregate demand and industrial production, the federal funds rate was reduced to below 3-1/2 percent early in the year and was held below 5 percent until the November election. Growth of the monetafy base remained above $6-1 / 2$ percent, and growth of $M_{1}$ increased to 7 percent. Nominal imports surged, reflecting the devaluation and the strong economic expansion. For the year as a whole, real net exports were $-\$ 49$ billion, a 20 percent rise in a single year and the largest deficit to that time. The nominal current account balance remained negative, $-\$ 5.8$ billion, more than four times the deficit of the previous year.

For a few months in the summer and fall, the dollar stabilized. Prices in the United States declined relative to trade weighted prices abroad (figure 3) and, until September, U.S, real interest rates rose relative to trade weighted real rates abroad (figure 6 ). The rise in the relative real interest rate during the fall and early winter was small, however, in relation to the capi" tal outflow.

In late January 1973, a new foreign exchange crisis began. Italy announced a two-tier exchange market to discourage capital outflows. Switzerland floated to reduce the flow from Italy and to control money growth. Pressure shifted to Germany and Japan. Within two weeks, Japan floated, and the Europeans closed their foreign exchange markets to halt the inflow of dollars. ${ }^{68}$

The United States made its last attempt to retain the par value system. On February 12, the dollar was devalued by 10 percent (to $\$ 42.22$ ). Since the United States did not intervene to maintain the new price, the action was more symbol than substance. Secretary Shultz twho had replaced Connally the previous summer) also announced an end to U.S. exchange controls, including the interest equalization tax and restrictions on foreign loans and investments scheduled for December 1974.69

Within a few weeks, there was a renewed flight from the dollar, requiring additional purchases by foreign central banks under the rules. During the first quarter of the year, foreign central banks, mainly in the G-10, bought an ad. ditional $\$ 10$ billion. The addition was more than 17 percent of total G-10 foreign exchange balances at the end of $1972{ }^{\text {ra }}$ The new purchases were suffictent to convince most countries to bring the Bretton Woods system to an end. The Europeans agreed on a joint float against the dollar and other currencies. The yen had floated earlier. De facto fluctuating exchanges rates became the norm for major currencies.

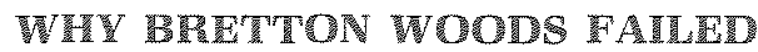

In retrospect, the Bretton Woods system of fixed but adjustable exchange rates appears to have failed for two main reasons. First, the system was poorly designed, and the flaws became more apparent as time passed. Second, the United States did not pursue the monetary policy necessary to maintain a fixed exchange rate. On a few occasions, interest rates may have been raised to support the exchange rates for to slow the capital flow), but monetary policy concentrated almost exclusively on a variety of domestic objectives. This was particularly true when the climax came in 1970-72.

\section{The Flaws in Bretion Woods}

The designers of the Bretton Woods system wanted to reduce the role of gold and make ad-

\footnotetext{
66See the Wall Street Journal, December 19, 1971.

67Previously Germany used reserve requirements on foreign deposits to reduce capital inflows. In June 1973 sales of German securities to foreigners were prohibited.

68The Bundesbank purchased $\$ 5$ biltion in the week ending February 9, 1973.
} 
justment by deficit and surplus countries more nearly symmetrical. One of the designers, John Maynard Keynes, believed that with fixed but adjustable exchange rates and adjustment by both deficit and surplus countries, fluctuations in economic activity would be reduced; deficit countries would not be forced to contract, or would contract less, when faced with a temporary loss of reserves; instead, surplus countries would lend to deficit countries. In this way, fluctuations in output would be damped.

There were two problems with this plan for adjustment. First, surplus countries had no incentive to adjust, and they were generally reluctant to do so. Keynes had proposed a penalty on surplus countries that accumulated reserves, but this proposal was eliminated early in the development of the Bretton Woods system. ${ }^{71} \mathrm{Se}$ cond, policymakers could not distinguish a temporary disequilibrium, to be resolved by borFowing and lending, from a permanent disequilibrium requiring a change in par values. In practice, the system became more rigid with the passage of time. Britain delayed devaluation for several years before 1967. France delayed devaluation in 1968. Germany, Japan and other surplus countries delayed revaluations. Japan supported the yen for a few weeks even after August 15, 1971, by intervening sizably to slow the yen's appreciation. ${ }^{72}$

The flaws in the system appeared quickly, although they were not always recognized as such. A starting point for the full operation of the system is 1959 , when currencies became convertible. By 1968, the dollar was de facto inconvertible into gold. Although the Bretton Woods system stumbled through the next several years, foreign central banks and governments, after March 1968, were discouraged from converting dollars into gold and did not do so. When some tried to convert, in August 1971, the U.S, formalized the restriction that had been in effect for more than three years by refusing to sell gold.

During the 10 years, 1959-68, from the move to convertibility to the effective embargo on U.S. gold, restrictions on trade and payments grew. The United States paid considerable costs to avoid buying supplies abroad for its troops in
Europe and Asia. Much foreign aid was tied to purchases from the United States. Restriction of capital movements by Britain, the United States and other countries made the payments system highly illiberal and complex.

The ideal of Bretton Woods was a system of fixed but adjustable exchange rates among convertible currencies. During its short life, the goal became increasingly one of maintaining fixed rates. Adjustment of exchange rates and convertibility of the dollar into gold were lost. President Nixon's August 1971 decision, in this light, should be seen as a choice of adjustment over gold convertibility.

\section{U.S.POLICY}

The professed principal aims of U.S. international economic policy included maintaining convertibility into gold and sustaining the Bretton Woods system. The policy failed in part because it was often short-sighted or wrong, in part because the United States placed much more weight on domestic concerns than on the maintenance of the world monetary system.

Throughout the 1960s, france urged, and the United States opposed, a revaluation of gold. The French argument was correct insofar as it recognized that a devaluation of the dollar against gold would increase the supply of world reserves and reduce dependence on the dollar as a reserve currency. The French were correct also in insisting that gold had a long history as an international money, but this argument confused rather than clarified the issues under discussion. Devaluation of the dollar against gold did not presuppose a change in the Bretton Woods system. That system was based on the dollar, a point that should have been completely clear after March 1968 when, de facto, countries could no longer convert dollars into gold. Had the United States agreed to revalue gold in 1965 or shortly after, it seems entirely possible that the many discussions leading to the issuance of SDRs would have been avoided and an adequate solution found for the liquidity problem much earlier. The U.S. policy delayed the solution until long past the time when it should have been apparent that a solution to the liquidity problem would not sustain the system.
71See Meltzer (1988).

72The European exchange rate mechanism had much greater flexibility in its early years, and Germany and the
Netherlands revalued several times. By the late 1980 s, however, countries tried to avoid exchange rate changes. 
Gold would have served as an effective means of payment between central banks, a role that the SDR did not acquire. More importantly for the Bretton Woods system, a revalued gold stock, if agreed to before 1968, could have imposed some discipline on the United States to pay in gold. Discipline was lacking once the de facto embargo on gold was in place after March 1968. Devaluation was not a panacea, however. Countries would have been unlikely to accept the cost of high U.S. inflation and frequent large devaluations against gold, so the system's survival would have required some restriction on U.S. policy. SDRs provided no discipline at all.

The arguments against gold revaluation were weak. The principal arguments were: (1) a devaluation of the dollar against gold would not solve the adjustment problem if other countries devalued against the dollar; (2) an increase in the gold price would benefit South Africa or the Soviet Union; (3) the gold standard was too rigid.

It is true that if all countries had devalued against the dollar, exchange rates would have remained fixed. But, the "liquidity" problem would have been solved and perhaps part of the "confidence" problem as well. Countries would have taken losses on their dollar reserves, but devaluation of the dollar would have reduced the risk that the system would collapse with a run on the dollar. Simultaneous devaluation would have focused attention on the adjustment problem by removing the liquidity problem that occupied so much time and attention.

Arguments about South Africa and the Soviet Union addressed domestic political concerns. These arguments had no practical relevance. In the end, the revaluation of gold was not avoided. South Africa and the Soviet Union continued to sell gold. The IMF established rules for purchasing South African gold that accepted South Africa's right to sell gold in the market and to member governments.

There is little reason to doubt that public opinion in many countries wanted to avoid a return to the gold standard. The gold standard was widely viewed as an excessively rigid, 19 th century system. Some of the French, who favored a greater role for gold, emphasized the "discipline of gold" and the repayment of dollar and sterling

73See Rueff (1969).

${ }^{74}$ There were many other private proposals including proposals for a world central bank. Haberler (1966), p. 9 liabilities. ${ }^{73}$ They wrote as if they did not want a more flexible system of adjustment; they wanted greater discipline. They talked much more about the losses on holdings of dollars than the gain from a more stable, adjustable monetary system. Although a return to a full gold standard was not the consistent aim of French policy toward the international monetary system, their proposals and arguments made it easy for others to dismiss their arguments. Neither France nor other governments offered alternative proposals under which U.S. monetary policy would be subject to discipline. ${ }^{74}$ Perhaps it was inevitable in the 1960 s that any alternative to U.S. policy would be dismissed.

The U.S. argument that the dollar could not be devalued was, at most, a half truth. The restrictions placed on various types of transactions were partial devaluations that changed the relative prices of those transactions. The most obvious example was the interest equalization tax which raised the cost of borrowing dollars. Import-export bank subsidies lowered the cost of favored U.S. exports. Other restrictions worked in much the same way to selectively devalue the dollar.

Some of the restrictions were so short-sighted as to raise doubts about the purpose of the policy and the objectives of the policymakers. Restrictions on investment abroad by U.S. firms are an obvious example. Absent the restrictions, investment abroad would have been higher and the capital outflow larger. But, profitable investment abroad would have produced a return flow, increasing the current account surplus in the future. Whatever short-term gain the restrictions achieved, they had long-term, negative consequences. The problem was not a shortterm problem of maintaining the Bretton Woods system for a few months or years. From a longer perspective the restrictions on investment were counter-productive.

One reason for the investment restrictions may have been that policymakers often focused on the basic balance or broader measures such as the official settlements balance. For these balances, U.S. long-term investment abroad is equivalent to an import of goods and services. Greater attention to the current account balance refers to such proposals as endowing "the creation of their fantasy with perfect foresight, infinite wisdom..." 
would have shown the steady decline in that balance, thereby concentrating attention on rela" tive costs and prices. This focus would have posed more sharply the basic issue: deflation or devaluation. Reliance on investment controls partially obscured this basic issue as well as sacrificing the future for small, costly improvemments in the present.

The interest equalization tax was no less shortsighted than the restrictions on investment. The effect of the tax was to raise the cost of trading in U.S. markets, thereby encouraging part of the financial service industry to move abroad. A long-term result was loss of the export of some financial services.

By far the major flaw in U.S. policy, and the most damaging feature of the Bretton Woods system, was the failure to prevent U.S. inflation. As the system developed, the United States was able to choose domestic over international goals whenever a choice had to be made. At times, particularly in the early 1960s, U.S. nominal in" terest rates were kept higher for a few weeks or months to reduce the capital outflow. But such choices usually were reversed if unemployment rose. U.S. policymakers typically chose expansion to deflation and used controls of various kinds to get temporary reductions in the capital outflow. And, after 1966, policymakers adopted more inflationary policies than before. Given the priority placed on employment and other domestic goods, such as housing, price stability was ruled out.

All of the responsibility for failure does not fall on the United States, Germany, Japan and others pursued export growth as a holy grail and either made few efforts to adjust their exchange rates or none at all. Spokesmen for Germany could point correctly to the inflationary policies of the United States, and the failure of the United States to adjust domestic policies so as to honor international commitments, but they were less forthright about the adjustment of countries with sustained surpluses that had undervalued currencies. ${ }^{75}$ After the Bretton Woods experience, Germany changed its policies toward adjustment. In the European Monetary System, Germany revalued frequently to keep that system from experiencing the adjustment problems of Bretton Woods.

It is surprising how little attention was paid to the adjustment problem. The Kennedy, Johnson and Nixon administrations did not propose a permanent solution ${ }^{76}$ Each so-called crisis left more controls on capital movements or other transactions, but these efforts were not followed by internal discussions of policies leading to a long-term solution in which controls would be removed. The Economic Reports of Presidents Kennedy, Johnson and Nixon have lengthy sections each year on the international monetary system, but the reports say little about adjustment. The typical comment was that surplus countries should revalue or expand demand. The explanation for neglect of adjustment is not that such discussions were sensitive. Solomon (1982) reports on the many meetings that were held during these years. There are pages on proposals and negotiations about liquidity, very little discussion of adjustment. The G-10 and the International Monetary Fund are no better. ${ }^{77}$ They, too, avoided the issue or limited their comments to suggestions that surplus countries expand without inflating. Even the devaluations by Britain and France were not followed by discussions of the effect of the devaluation on the United States.

As the Bretton Woods system developed, it acquired some of the characteristics its designers had hoped to avoid. Major countries were reluctant to change parities. Surplus countries argued that adjustment was the responsibility of deficit countries. Deficit countries made opposite arguments, appealing to the need for symmetry,

The 1960s witnessed the beginning of efforts to solve international monetary or economic problems by coordinating policy actions. In practice, this usually meant that surplus and deficit countries were supposed to agree on different mixes of monetary and fiscal policy actions. Discussions produced few concrete steps. Foreign countries accepted the expansions implied by the flows of U.S. dollars, but they did not systematically reduce government spending or raise taxes to slow their expansions and lower domestic interest rates. And, as discussed earlier, the United States focused mainly on domestic
75See Emminger (1967) as an example. Otmar Emminger was a director and later president of the Deutsche Bundesbank.

76 See Shultz and Dam (1971), p. 111. Milton Friedman sent a long memo to Presidentelect Nixon in December 1968 urging a prompt, decisive change in policy. Nothing was done. See Friedman (1988).

77 See Solomon (1982), p. 173. 
objectives. The dialogue about coordination, once started, was hard to stop. It continued into the 1970 s and 1980s. Countries that faced a balance of payments deficit usually favored coordinated action. Countries in surplus usually were opposed.

The end of the Bretton Woods system was followed by diverse predictions. Some saw fluctuating exchange rates as a means of increasing stability or domestic policy. Some warned about the instability that would follow. It is now clear that neither was correct. The warnings about the consequences of the collapse of Bretton Woods proved to be wrong. The inconvertible dollar continued to function as an international medium of exchange and store of value. The accumulation of dollar assets by foreign central banks and governments continued to rise. By the end of the 1970s, nominal dollar reserves of the G-10 countries, excluding the United States, had doubled from the level at the end of 1972 . In the next decade, these reserves doubled again to more than $\$ 300$ billion. Central banks and governments continued to be more willing to acquire additional dollars than to allow the dollar to devalue.

The end of Bretton Woods improved the adjustment mechanism, but did not quickly eliminate inflation or inflationary policies. Countries gained the opportunity to pursue independent policies. Inflation differed between major currencies but both governments and some private individuals complained about the variability of nominal and real exchange rates. During most of the next 20 years, the principal currencies continued to fluctuate.

However, countries did not float freely. Dirty floating, managed exchange rates, intervention, exchange controls and trade restrictions were retained or introduced. Despite these policies and complaints about excessive variability of exchange rates, there was no interest in a return to Bretton Woods.

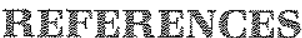

Corden, Max. "Does the Cutrent Account Matter? The Old View and the New" unpublished paper (Johns Hopkins Universify, 1990)
Economic Report of the President (Government Printing Office, various years),

Emminger, Otmar, "Practical Aspects of the Problem of Balance-of-Payments Adjustment," Journal of Political Economy, Vol. 75 (Augusì 1967, Part li), pp. 512-22.

Friedman, Milton. "The Case for Flexible Exchange Rates," in M. Friedman, ed., Essays in Positive Economics (University of Chicago Press, 1953), pp. 157-203.

"A Proposal for Resolving the U.S. Balance of Payments Problem," in Leo Melamed, ed., The Merits of Flexible Exchange Rates: An Anthology (George Mason University Press, 1988), pp. 429-38.

Haberier, Gottried. Money in the International Economy (Harvard University Press, 1965).

"The International Payments System: Posiwar Trends and Prospects," in International Payments Problems: A Symposium Sponsored by the American Enterprise institute (Washington: American Enterprise Instítite, 1965), pp. $1-16$.

Heller, Walter. Now Dimensions of Poltical Economy (Harvard University Press, 1966).

International Monetary Fund. Annual Report, vatious years.

Keynes, J.M. A Iract on Monetary Reform (London: Macmillan, 1923), reprinted as vol. 4 of The Collected Writings of John Maynard Keynes (London: Macmillan, 1971).

Meltzer, Allan H. Keynes's Monetary Theory: A Different Interpretation (Cambridge University Press, 1988).

Okun, Arthur M. The Political Economy of Prosperity. (Washington: The Brookings Institution, 1970).

Pauls, B. Dianne. "U.S. Exchange Rate Policy: Bretton Woods to Present," Federal Reserve Bulletin, vol. 76 (November 1990), pp. 891-908.

Rueff, Jacques. "The Rueff Approach," in R. Hinshaw, ed., Monetary Reform and the Price of Gold. (The Johns Hopkins Press, 1967), pp. 37-46.

Salant, Walter, and others. The United States Balance of Payments in 1968. (Washington: The Brookings Institution, 1963).

Schwartz, Anna J. "The Postwar Institutional Evolution of the International Monetary System," in A.J. Schwartz, ed., Money in Historical Perspective (University of Chicago Press for the National Bureau of Economic Research, 1987), pp. 333-63.

"The Performance of the Federal Reserve in Pursuing International Monetary Objectives," Money and Banking: The American Experience (Durrell Foundation, 1991).

Shultz, George P., and Kenneth W. Dam. Economic Policy Beyond the Headlines. (Stanford University Press, 1977).

Solomon, Robert. The International Monetary System, 1945-1981 (Harper \& fow, 1982).

Sorensen, Theodore. Kennedy. (Harper \& Row, 1965). pp. 405-12.

Stein, Herbert. Presidential Economics, 2nd rev. ed. (Washington: American Enterprise Institute for Public Policy Research, 1988).

The Wall Street Joumal, December 19, 1971. 